\title{
Phytoplankton productivity enhancement and assemblage change in the upstream Kuroshio after typhoons
}

\author{
Yuh-ling Lee Chen ${ }^{1,2, *}$, Houng-Yung Chen ${ }^{2,3}$, Sen $\mathrm{Jan}^{4}$, Sing-how Tuo ${ }^{1}$ \\ ${ }^{1}$ Department of Marine Biotechnology and Resources, and ${ }^{2}$ Asia-Pacific Ocean Research Center, and \\ ${ }^{3}$ Institute of Marine Biology, National Sun Yat-sen University, Kaohsiung 80424, Taiwan \\ ${ }^{4}$ Institute of Hydrological and Oceanic Sciences, National Central University, Jung-li 32001, Taiwan
}

\begin{abstract}
The primary production (PP), nitrate-uptake-based new production $\left(\mathrm{NO}_{3}-\mathrm{NP}\right)$, chlorophyll a concentration, and phytoplankton assemblage in the upstream Kuroshio Current neighboring the northern South China Sea (SCS) before and after the consecutive passage of 3 typhoons during the summer of 2007 were compared. The aim was to elucidate the effects of riverine mixing on phytoplankton dynamics in the oligotrophic Kuroshio, to which northern SCS and Taiwan coastal water spread after the typhoons. Spatial changes in surface salinity were used to differentiate the effects of riverine mixing from wind-induced upwelling. After the typhoons, $\mathrm{PP}$ and $\mathrm{NO}_{3}-\mathrm{NP}$ in the Kuroshio both were higher due to enriched nutrients from entrainment of riverine-mixed waters. Abundances of diatoms had increased but the abundances of Trichodesmium spp., Richelia intracellularis, and unicellular potential diazotrophs that typically thrive in the summer were reduced. Specifically, oligotrophic coccolithophores, such as Umbellosphaera tenuis and Discosphaera tubifera, were replaced by Gephyrocapsa oceanica and Emiliania huxleyi, and Prochlorococcus sp. was replaced by Synechococcus spp. The shift of the phytoplankton community from Trichodesmium spp. to diatoms suggests that the biogenic carbon enhanced by the typhoons tended to sink rather than be recycled in the upper-water food web.
\end{abstract}

KEY WORDS: Typhoon - River mixing - Production - Phytoplankton assemblages - Trichodesmium spp. $\cdot$ Kuroshio $\cdot$ South China Sea

\section{INTRODUCTION}

Significant biogeochemical changes occur in the upper ocean waters as a typhoon passes with its cyclonic winds and intensified precipitation. In the surface water affected by the typhoon, nutrient concentrations and phytoplankton biomass often are significantly increased as winds induce vertical mixing, upwelling, or both (Lin et al. 2003, Babin et al. 2004). Wind-induced water mixing is detected as cool anomalies within the upper thermocline. Upwelling leads to saltier anomalies at the ocean surface. In addition to wind-induced water mixing and upwelling, in coastal waters where river discharge is significant, nutrient concentrations and phytoplankton biomass are increased by entrainment of waters from river runoff from typhoon-related floods (Chen \& Chen 2006). This is especially important in areas with numerous small mountainous rivers (SMRs), which are the major source of particulate and dissolved organic carbon fluxes to the ocean (Goldsmith et al. 2008). In this respect, surface salinity is a convenient or even an essential parameter to quantify the effects of riverine discharge and to distinguish between the importance of upwelling and riverine mixing in increasing ocean productivity when typhoons pass. Unfortunately, sur- 
face salinity is not available from remote sensing, which, with its easy availability and wide spatial coverage, has become a preferred tool to study the effects of typhoons.

Ocean surface temperature and chlorophyll concentration are widely used to study biogeochemical responses to typhoons via remote sensing (Lin et al. 2003, Walker et al. 2005). Prolonged cloudiness along the typhoon's trajectory, however, often hampers collection of images that reveal the most recent conditions of the ocean surface. Primary production (PP) changes following typhoons are usually estimated from satellite-derived chlorophyll concentrations and temperature through models that describe their relationships (e.g. Lin et al. 2003). Nevertheless, many factors affect the estimates of phytoplankton production from satellite-derived chlorophyll a (chl a) concentrations from before and after typhoons. Increased concentrations of surface chlorophyll within the cool wakes of a typhoon could come from the rapid growth of phytoplankton responding to the injection of nutrients from the deep, or from phytoplankton brought up by vertical displacement from the deep chlorophyll maximum layer, or both (Babin et al. 2004). In addition, partial removal of zooplankton after a typhoon reduces grazing on phytoplankton (Zhang \& Wang 2000). These various factors could work singly or in combination to affect the magnitude of change in chlorophyll concentration. Our understanding of this phenomenon is quite limited.

The biogeochemical effects of a typhoon on the upper ocean are often more pronounced if it passes through shallow waters rather than deep waters (Siswanto et al. 2007), or deep waters having a shallow nitracline (Babin et al. 2004). Kuroshio, which is a current originating at the equator, flows mostly over bottom depths $>3000 \mathrm{~m}$. The main stream of its upstream current in the West Philippine Sea between Taiwan and the Philippines (see Fig. 1) is characterized by a nitracline (73 $\mathrm{m}$; Chen et al. 2008) deeper than the neighboring South China Sea (SCS, 30 to $40 \mathrm{~m}$; Chen 2005). The effects of a typhoon on the biogeochemical dynamics of the upstream Kuroshio via upwelling or deep-water mixing, although yet be studied, could be less pronounced than those in the shallow coastal waters or deep waters with shallow nitracline. On the other hand, Chern \& Wang (1998) reported that surface SCS water could spread to the Kuroshio in the summer when a southwest monsoon prevails. As a typhoon is always accompanied by significant river discharge, the roles of riverine mixing in the Kuroshio could be important, although whether Taiwan Strait coastal water would reach and mix with the Kuroshio via the northern SCS remains to be studied.

Because of their tropical origin, the surface waters of the Kuroshio are generally regarded as oligotrophic and nitrogen-deficient; however, nitrogen fixation from Trichodesmium spp., filamentous cyanobacteria that flourish in the Kuroshio, and perhaps from other diazotrophs, renders the upstream Kuroshio relatively productive in the summer when the nitracline deepens and nitrate-uptake-based new production $\left(\mathrm{NO}_{3}-\mathrm{NP}\right)$ is low (Chen et al. 2008). The standing crop of Trichodesmium spp. is consistently higher in the Kuroshio than in the SCS, which is attributed to differences in the nitracline depth and nitrate availability (Chen et al. 2008). Because the passage of a typhoon could affect the supply of nitrogen, how that affects the dominance of Trichodesmium spp. in the upstream Kuroshio and the dynamics of the carbon and nitrogen pools in the whole ecosystem are unknown. On average, 4 typhoons pass through Taiwan and the Kuroshio region every year. Their effects could be substantial in this oligotrophic oceanic region.

In this paper, we present the evolution of $\mathrm{PP}, \mathrm{NO}_{3}$ $\mathrm{NP}$, and phytoplankton community composition before and after the consecutive passage of 3 typhoons in the upstream Kuroshio during the southwest monsoon season of 2007. Surface salinity was used to elucidate and differentiate the effects of upwelling and riverine mixing. To our knowledge, although relevant studies have been conducted in lakes (James et al. 2008) and estuaries (Paerl et al. 2006), this is the first paper reporting the effects of typhoons on phytoplankton assemblage and new production in open ocean water.

\section{MATERIALS AND METHODS}

Cruises. Results from a pre-typhoon cruise (CR1234) during 7-10 July 2007 and a post-typhoon cruise (CR1242) during 21-25 August 2007 were compared. Between the 2 cruises, 3 typhoons, Pabuk (7-8 August), Wutip (8-9 August), and Sepat (17-18 August) passed over the Kuroshio and the island of Taiwan (Fig. 1). CR1234 was conducted before Pabuk, which was the first typhoon that made landfall on Taiwan during 2007. CR1242 was commenced 4 d after Sepat, a super-typhoon with a moving speed of $5.44 \mathrm{~m} \mathrm{~s}^{-1}$ and a gust wind speed of $57 \mathrm{~m} \mathrm{~s}^{-1}$ before landfall.

Sampling stations. Four sampling stations (K1 to K4) along Transect K (Fig. 1), which was oriented perpendicularly to the Kuroshio from the southern tip of Taiwan $\left(21^{\circ} 55^{\prime} \mathrm{N}\right)$, were surveyed during both cruises. The main axis of the upstream Kuroshio is reported to be between $121^{\circ}$ and $123^{\circ} \mathrm{E}$ along $22^{\circ} \mathrm{N}$ (Liang et al. 2003). Transect $K$ was located to the west of the trajectories of the typhoons. Stns K4 and K1 were located 63 and $156 \mathrm{~km}$ away from the path of the center of Typhoon Sepat, respectively (Fig. 1). In addition, CTD 
measurements were conducted at Stns N1 and S1 to S5 (Fig. 1) during CR1242 to identify the flow path of the Kuroshio.

Data collection. During the cruises, CTD casts, water collections, and onboard simulated experiments for PP and $\mathrm{NO}_{3}-\mathrm{NP}$ were conducted. Seawater was collected in 201 Go-Flo bottles from 6 depths corresponding to $100,46,38,13,6$, and $0.8 \%$ of surface irradiance. Aliquots of the water samples were used to analyze chl a concentration and nanomolar-level concentrations of nitrate and nitrite $(\mathrm{N}+\mathrm{N})$ and soluble reactive phosphorus (SRP), and to identify and enumerate the standing crops of diatoms; diazotrophs Trichodesmium spp., Richelia intracellularis, and unicellular cyanobacteria; and picophytoplankton. A Seabird SBE-9 CTD and a photosynthetically active radiation (PAR) sensor (OSP200L, Biospherical) were attached to the rosette frame of the Go-Flo bottles. Surface water temperature and salinity were measured continuously along the cruise tracks by pumping surface water through a Seabird SBE-11 deck monitoring probe. Water current direction and velocity along the cruise tracks were measured by a $150 \mathrm{kHz}$ shipboard acoustic Doppler current profiler (Sb-ADCP; Teledyne RD Instruments). The Sb-ADCP was set with a bin depth of $8 \mathrm{~m}$, an average time interval of $1 \mathrm{~min}$, and a blanking depth of

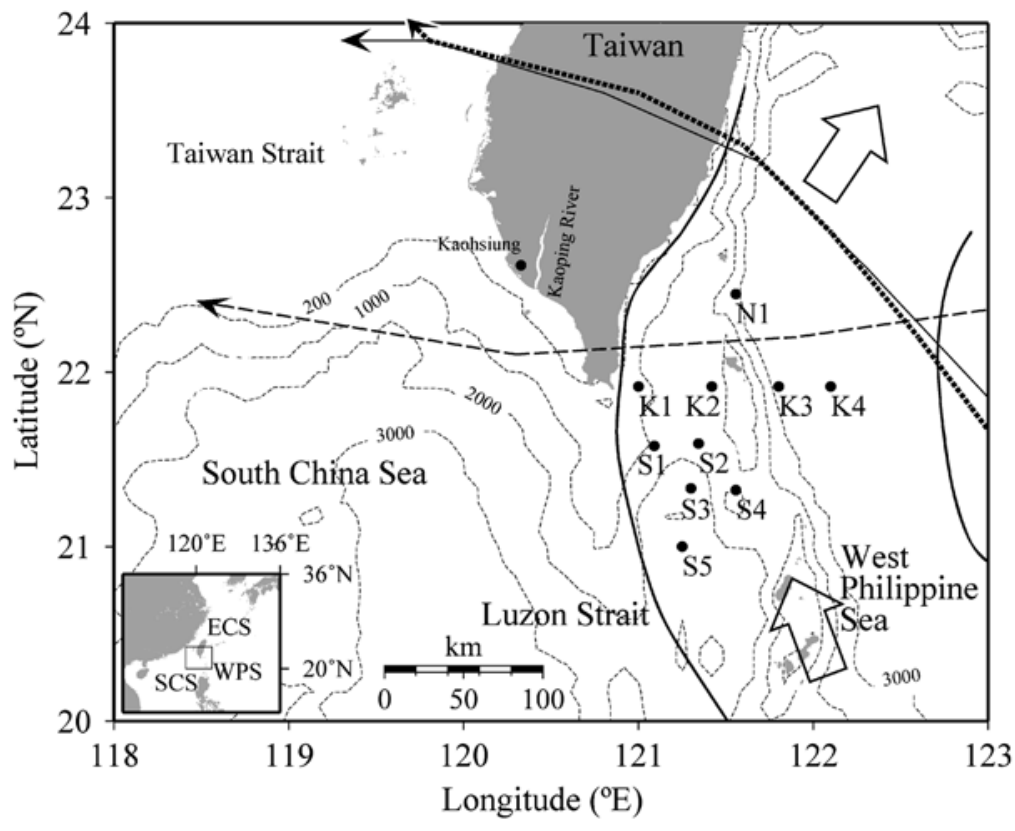

Fig. 1. Bottom topography, locations of sampling stations (N1, S1 to S5, $\mathrm{K} 1$ to K4), and the trajectories of 3 typhoons, Pabuk (thin dashed arrow, 7-8 August), Wutip (solid arrow, 8-9 August), and Sepat (thick broken arrow, 17-18 August) that passed through the upstream Kuroshio Current in the West Philippine Sea (WPS). Flow direction (unfilled arrow) and boundary (solid line) of the Kuroshio are after Liang et al. (2003). ECS: East China Sea; SCS: South China Sea
$15 \mathrm{~m}$ below the sea surface. The high-frequency tidal currents, which were obtained from a $1 \% 12$ horizontalresolution, carefully tuned 2-dimensional tide model (Jan et al. 2002), were subtracted from the raw SbADCP data after the cruises. The subtidal currents were re-sampled to be an hourly data set with a $1 \mathrm{~h}$ running mean filter, and were used to investigate the source of the less-saline water mass and associated nutrient entrainment after the typhoons. To facilitate the explanation, the absolute geostrophic velocities derived from the satellite altimeter measuring seasurface height were collected from AVISO (Archiving, Validation and Interpretation of Satellite Oceanographic data) at http://las.aviso.oceanobs.com/las/ servlets/dataset. (The altimeter products were produced by Ssalto/Duacs and distributed by AVISO with support from the Centre National d'Etudes Spatiales.)

Production experiments. $\mathrm{PP}$ and $\mathrm{NO}_{3}-\mathrm{NP}$ were measured by the ${ }^{13} \mathrm{C}\left(\mathrm{NaH}^{13} \mathrm{CO}_{3}\right)$ and ${ }^{15} \mathrm{~N}\left(\mathrm{Na}^{15} \mathrm{NO}_{3}\right)$ tracer methods, respectively. The protocols of the onboard simulation experiments are detailed in Chen et al. (2008). Briefly, incubation water was collected from the 6 light depths. After additions of the tracers, the incubations were started between approximately 08:00 and 09:00 $\mathrm{h}$ and lasted for $3 \mathrm{~h}$. Before incubation, $\mathrm{NaH}^{13} \mathrm{CO}_{3}$ (99 atom \%, Isotec, Sigma-Aldrich) solution was added into the PP bottles to a final concentration of $0.19 \mathrm{mM}$. The $\mathrm{Na}^{15} \mathrm{NO}_{3}$ solution was added to the NP bottles at a concentration equivalent to one-tenth of ambient nitrate concentration, which was determined with a detection limit of $0.5 \mu \mathrm{M}$ by an onboard flow-injection analyzer adapted to the pink azo dye method. Whenever the ambient nitrate concentration was below the detectable limit, $0.03 \mu \mathrm{M}$ of $\mathrm{Na}^{15} \mathrm{NO}_{3}$ was added to the ambient water sample and frozen for later measurement by the chemiluminescent method. The initial and incubated waters were filtered through precombusted $\left(450^{\circ} \mathrm{C}, 4 \mathrm{~h}\right)$ Whatman GF/F filters and fumed for $2 \mathrm{~h}$ with $\mathrm{HCl}$ to remove carbonate. Concentrations of particulate organic carbon and particulate nitrogen and the isotopic ratios of ${ }^{13} \mathrm{C}:{ }^{12} \mathrm{C}$ and ${ }^{15} \mathrm{~N}:{ }^{14} \mathrm{~N}$ were analyzed using the ANCA 20-20 mass spectrometer (Europa Scientific). Nitrogen was converted to carbon by assuming the molar Redfield ratio stoichiometry of $\mathrm{C}: \mathrm{N}=6.6$.

Phytoplankton counts. Specimens for enumeration of Trichodesmium spp. and Richelia intracellularis were prepared on board by filtering an aliquot of 1.2 or $2.4 \mathrm{l}$ seawater onto a $10 \mu \mathrm{m}$ Nuclepore filter 
(25 mm diameter). The filter paper was mounted with immersion oil and a cover slip on a microscope slide and kept in darkness at $-20^{\circ} \mathrm{C}$ until microscopic examination. Trichomes of Trichodesmium spp. and heterocysts of $R$. intracellularis were counted on the entire filter at a magnification of 100 to $400 \times$ with blue excitation using a Zeiss epifluorescence microscope. Depth-integrated abundances were calculated by trapezoidal integration from the surface to $100 \mathrm{~m}$ depth and expressed as trichomes $\mathrm{m}^{-2}$ or heterocysts $\mathrm{m}^{-2}$. A 1.21 surface water sample was reverse-filtered through a $20 \mu \mathrm{m}$ mesh Nitex screen to remove large organisms and then filtered onto a $1 \mu \mathrm{m}$ Nuclepore $(25 \mathrm{~mm}$ diameter) to collect unicellular cyanobacteria with diameters between 2.5 and $10 \mu \mathrm{m}$, which represent potential unicellular diazotrophs. The preparation and observation of the specimens were similar to those used for the other diazotrophs except that a magnification of 1000x was needed. The unicellular cyanobacteria in 2 size fractions $(2.5-5 \mu \mathrm{m}$ and $5-10 \mu \mathrm{m})$ were counted. Diatoms in $100 \mathrm{ml}$ of formalin-preserved surface-water samples were counted after settling in a Utermöhl chamber for $24 \mathrm{~h}$. The diatoms were examined at $400 \times$ magnification on a Zeiss Axiovert 35 inverted microscope with phase contrast optics. Coccolithophores in surface-water samples from Stns K1 and K2 with 5\% neutralized formalin added were filtered under a vacuum pressure of $100 \mathrm{~mm} \mathrm{Hg}$ onto $0.45 \mu \mathrm{m}$ Nuclepore polycarbonate membrane filters (25 $\mathrm{mm}$ diameter). The filters were subsequently rinsed with buffered distilled water ( $\mathrm{pH} 8$ to 9) and oven-dried at $40^{\circ} \mathrm{C}$ for at least $12 \mathrm{~h}$. The procedures for scanning electron microscopy and taxonomic identification are described in Chen et al. (2007). Counts of coccoliths were converted to counts of coccospheres according to speciesspecific factors. Cell densities of Prochlorococcus sp. and Synechococcus spp. were examined to represent the picophytoplankton population. A $1 \mathrm{ml}$ aliquot of seawater from 6 to 9 depths to $200 \mathrm{~m}$ depth was preserved with paraformaldehyde $(0.2 \%$ final concentration), frozen in liquid nitrogen, and stored at $-80^{\circ} \mathrm{C}$ before flow cytometric analysis (Vaulot et al. 1989). An inFlux Mariner cell sorter (Cytopeia) that was equipped with a $200 \mathrm{~mW}$ laser (excitation at $488 \mathrm{~nm}$ ) was used to enumerate the cell densities of Prochlorococcus sp. and Synechococcus spp. following the method of Campbell (2001).

Calculations. Chl a concentrations were determined fluorometrically. $\mathrm{N}+\mathrm{N}$ concentrations were measured by the chemiluminescent method (Garside 1982). SRP was determined to nanomolar levels by the modifiedMAGIC method (Thomson-Bulldis \& Karl 1998). Depth of the euphotic zone $\left(D_{\text {eu }}\right)$ was defined as the depth at which light intensity was $0.8 \%$ of surface irradiance. The nitracline depth $\mathrm{D}_{\text {ni }}$ was defined as the depth at which $\mathrm{N}+\mathrm{N}$ equaled $0.1 \mu \mathrm{M}$ and was used as an index to infer nitrate availability to phytoplankton in the upper water column. $\mathrm{D}_{\text {chl-max }}$ is defined as depth of chl a maximum. Depth-integrated production was calculated by trapezoidal integration of the entire euphotic zone (0.8 to $100 \%$ of surface irradiance) for PP (IPP) and $\mathrm{NO}_{3}-\mathrm{NP}\left(\mathrm{INO}_{3}-\mathrm{NP}\right)$, and expressed as $\mathrm{g} \mathrm{C} \mathrm{m}^{-2}$. Daily production rates were calculated by extrapolating the rates of the $3 \mathrm{~h}$ incubations to $24 \mathrm{~h}$ rates, based on the short-term uptake rates and photoperiod conversion factors that have been established following the method of Cochlan et al. (1991). Depth-integrated $\mathrm{N}+\mathrm{N}(\mathrm{IN}+\mathrm{N})$ and chl a (IChl) were also calculated by integration from surface to $70 \mathrm{~m}$ and surface to $150 \mathrm{~m}$, respectively.

\section{RESULTS}

\section{Water properties}

Before the typhoons, surface Kuroshio water measured during CR1234 had typical salinities $>34.2$ (Fig. 2). Along Transect $K$, the only station with surface salinity <34.0 was K1. After Typhoon Sepat, a thick layer of less-saline water (33.1 to 33.8) was found to occupy the upper $50 \mathrm{~m}$ of the water column during CR1242 (Table 1). Stns K2 to K4 showed a typical Kuroshio subsurface salinity maximum of $>34.8$ at about $200 \mathrm{~m}$ depth before the typhoons and disappeared after the typhoons (Fig. 2). Similarly, water temperature was lower throughout the upper $400 \mathrm{~m}$ after the typhoons, by 1 to $2^{\circ} \mathrm{C}$ in the near surface (Fig. 3). The $21^{\circ} \mathrm{C}$ isotherm-measured pre-typhoon was $210 \mathrm{~m}$ deep at Stn K4 and shoaled to $120 \mathrm{~m}$ at Stn K1; post-typhoon, it was significantly uplifted to 150 and $80 \mathrm{~m}$ at the respective stations. Our results on surface salinity and current pattern suggest that this spread of low water temperature after the typhoons was not an indication of wind-induced upwelling, but instead the signature of influx of SCS water to the Kuroshio.

The temperature-salinity (T-S) diagrams revealed a significant influx of less-saline water from the northern SCS to the Kuroshio after the typhoons. Before the typhoons, the T-S diagrams for Stns K2 to K4 were typical of the upper water column of the Kuroshio (Fig. 4A), but Stn K1 was more similar to the SCS water. After the typhoons, the T-S diagrams of the upper water column along Transect $\mathrm{K}$ all resembled SCS waters (Fig. 4B). Because the minimum salinities in the deeper water column are lower in Kuroshio than in the SCS, the shifted T-S plots of the 4 stations toward those of the SCS suggests that Transect K received more waters from the SCS after the typhoons than before. Before the typhoons, the T-S properties in 


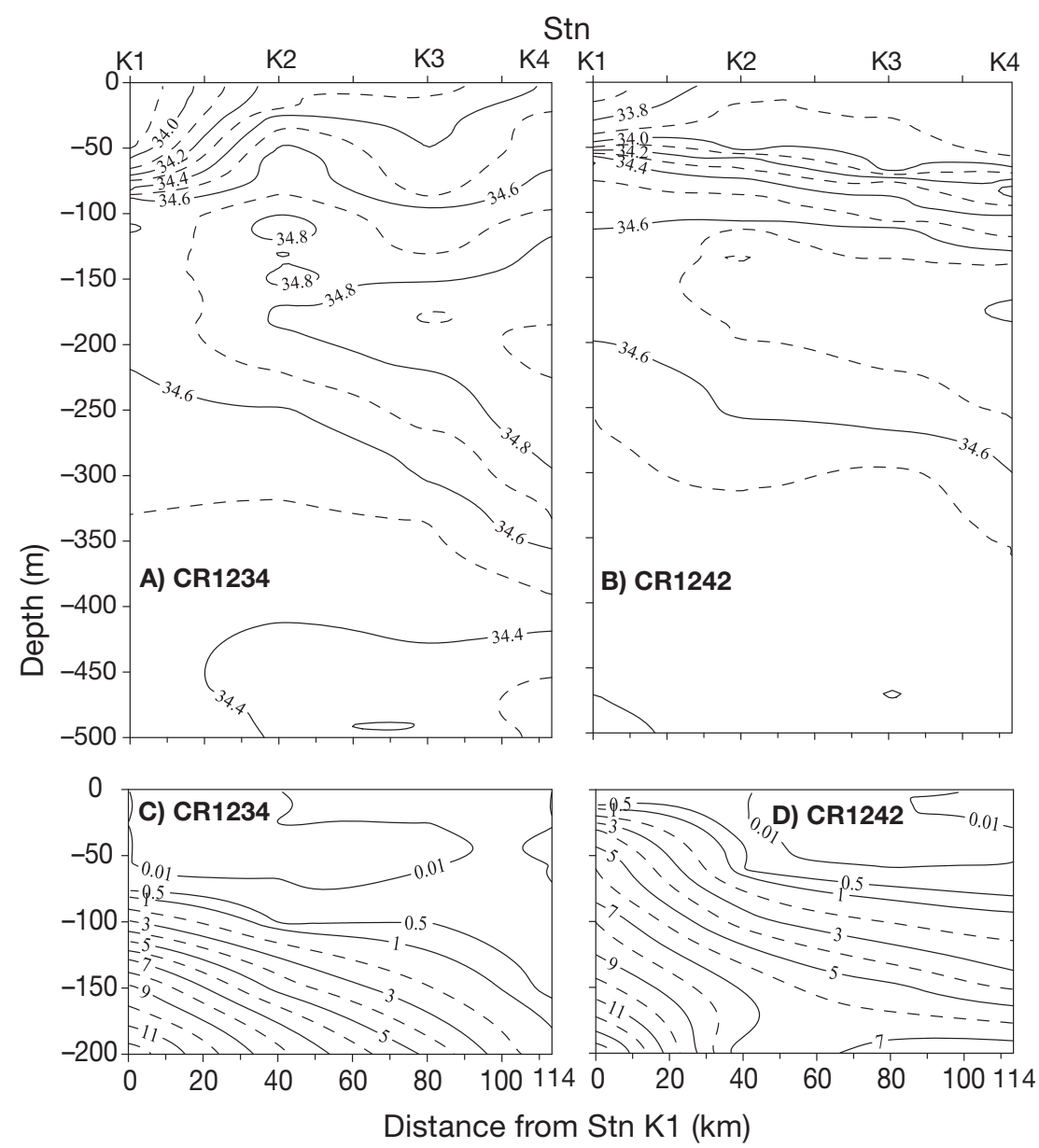

Fig. 2. Vertical profiles of $(A, B)$ salinity and $(C, D)$ nitrate plus nitrite concentration $(\mu M)$ at Transect $\mathrm{K}$ in the Kuroshio Current before (CR1234, 7-10 July) and after (CR1242, 21-25 August, 2007) the typhoons the deep water column resembled Kuroshio water only at Stn K4 (Fig. 4A). After the typhoons, all stations had deep water column T-S signatures similar to SCS water (Fig. 4B). These T-S shifts could result from either an eastward meander of the Kuroshio axis or an influx and mixing of less-saline water from the SCS posttyphoons; however, the surface T-S of Stns S1 and S3 to S5 were characteristic of the Kuroshio (Fig. 4C), and Stn N1 with T-S properties between Kuroshio and SCS waters was similar to Stns K2 and K3. This suggests that after the typhoons, a branch of surface SCS water joined the Kuroshio between $21^{\circ} 30^{\prime} \mathrm{N}$ and $22^{\circ} \mathrm{N}$. This signal of SCS water inflow was detected as far as Stn N1 at $22^{\circ} 30^{\prime} \mathrm{N}$.

\section{Spread of surface SCS water to Kuroshio}

Analyses of Sb-ADCP data indicated a strong eastward shift of currents along Transect $K$ after the typhoons, but not before (Fig. 5). Similar strong eastward currents were observed around $121^{\circ} \mathrm{E}$ between $21^{\circ}$ and $22^{\circ} \mathrm{N}$ in north Luzon Strait after the typhoons, but those stations were not sampled pre-typhoon. Pre- and

Table 1. Surface water temperature, salinity, nitrate plus nitrite concentration $(\mathrm{N}+\mathrm{N})$, phosphate concentration (SRP), watercolumn-integrated (surface to $70 \mathrm{~m}$ ) nitrate plus nitrite concentration (IN+N $\mathrm{N}_{70 \mathrm{~m}}$ ), surface chl a concentration, water-columnintegrated chl a concentration from the surface to $150 \mathrm{~m}$ (IChl), depth of chl a maximum $\left(\mathrm{D}_{\mathrm{Chl}-\mathrm{max}}\right)$, depth of euphotic zone $\left(\mathrm{D}_{\text {eur }}\right.$ $0.8 \%$ of surface light intensity), and nitracline depth $\left(\mathrm{D}_{\text {ni, }}\right.$ defined as depth with $\left.0.1 \mu \mathrm{M} \mathrm{NO} \mathrm{NO}_{3}\right)$ at Stns $\mathrm{K} 1$ to $\mathrm{K} 4$ before (7-10 July) and after (21-25 August, 2007) the typhoons

\begin{tabular}{|c|c|c|c|c|c|c|c|c|c|c|}
\hline Stn & $\begin{array}{l}\text { Temp } \\
\left({ }^{\circ} \mathrm{C}\right)\end{array}$ & Salinity & $\begin{array}{l}\mathrm{N}+\mathrm{N} \\
(\mathrm{nM})\end{array}$ & $\begin{array}{l}\text { SRP } \\
(\mathrm{nM})\end{array}$ & $\begin{array}{c}\mathrm{IN}+\mathrm{N}_{70 \mathrm{~m}} \\
\left(\mathrm{mmol} \mathrm{m} \mathrm{m}^{-2}\right)\end{array}$ & $\begin{array}{c}\mathrm{Chl} a \\
\left(\mathrm{mg} \mathrm{m}^{-3}\right)\end{array}$ & $\begin{array}{c}\mathrm{IChl} \\
\left(\mathrm{mg} \mathrm{m}^{-2}\right)\end{array}$ & $\begin{array}{l}\mathrm{D}_{\text {Chl-max }} \\
(\mathrm{m})\end{array}$ & $\begin{array}{l}D_{\text {eu }} \\
(\mathrm{m})\end{array}$ & $\begin{array}{l}D_{\text {ni }} \\
(\mathrm{m})\end{array}$ \\
\hline \multicolumn{11}{|c|}{ Before typhoons (CR1234) } \\
\hline K1 & 30.3 & 33.8 & 13 & 13 & 3.6 & 0.10 & 33.9 & 76 & 130 & 59 \\
\hline $\mathrm{K} 2$ & 30.0 & 34.2 & 11 & 22 & 1.9 & 0.10 & 25.9 & 100 & & 68 \\
\hline K3 & 30.6 & 34.2 & 9 & 38 & 3.5 & 0.08 & 31.0 & 100 & & 67 \\
\hline K4 & 30.4 & 34.4 & 10 & 21 & 0.8 & 0.06 & 20.7 & 134 & 134 & 95 \\
\hline Mean \pm SE & $30.3 \pm 0.1$ & $34.2 \pm 0.1$ & $10.8 \pm 0.85$ & $23.5 \pm 5.2$ & $2.5 \pm 0.7$ & $0.09 \pm 0.01$ & $27.9 \pm 2.9$ & $103 \pm 12$ & & $72 \pm 8$ \\
\hline \multicolumn{11}{|c|}{ After typhoons (CR1242) } \\
\hline K1 & 28.6 & 33.1 & 390 & 45 & 264.6 & 0.56 & 15.2 & 2 & 55 & 0 \\
\hline K2 & 28.7 & 33.8 & 26 & 15 & 13.2 & 0.23 & 24.9 & 29 & 127 & 33 \\
\hline K3 & 28.9 & 33.8 & 8 & 25 & 3.5 & 0.26 & 29.5 & 60 & & 62 \\
\hline K4 & 29.3 & 33.7 & 65 & 17 & 3.7 & 0.13 & 20.8 & 61 & 142 & 63 \\
\hline Mean \pm SE & $28.9 \pm 0.2$ & $33.6 \pm 0.1$ & $122.3 \pm 90.0$ & $25.5 \pm 6.9$ & $71.3 \pm 64.5$ & $0.30 \pm 0.09$ & $22.6 \pm 3.0$ & $38 \pm 14$ & & $40 \pm 15$ \\
\hline
\end{tabular}




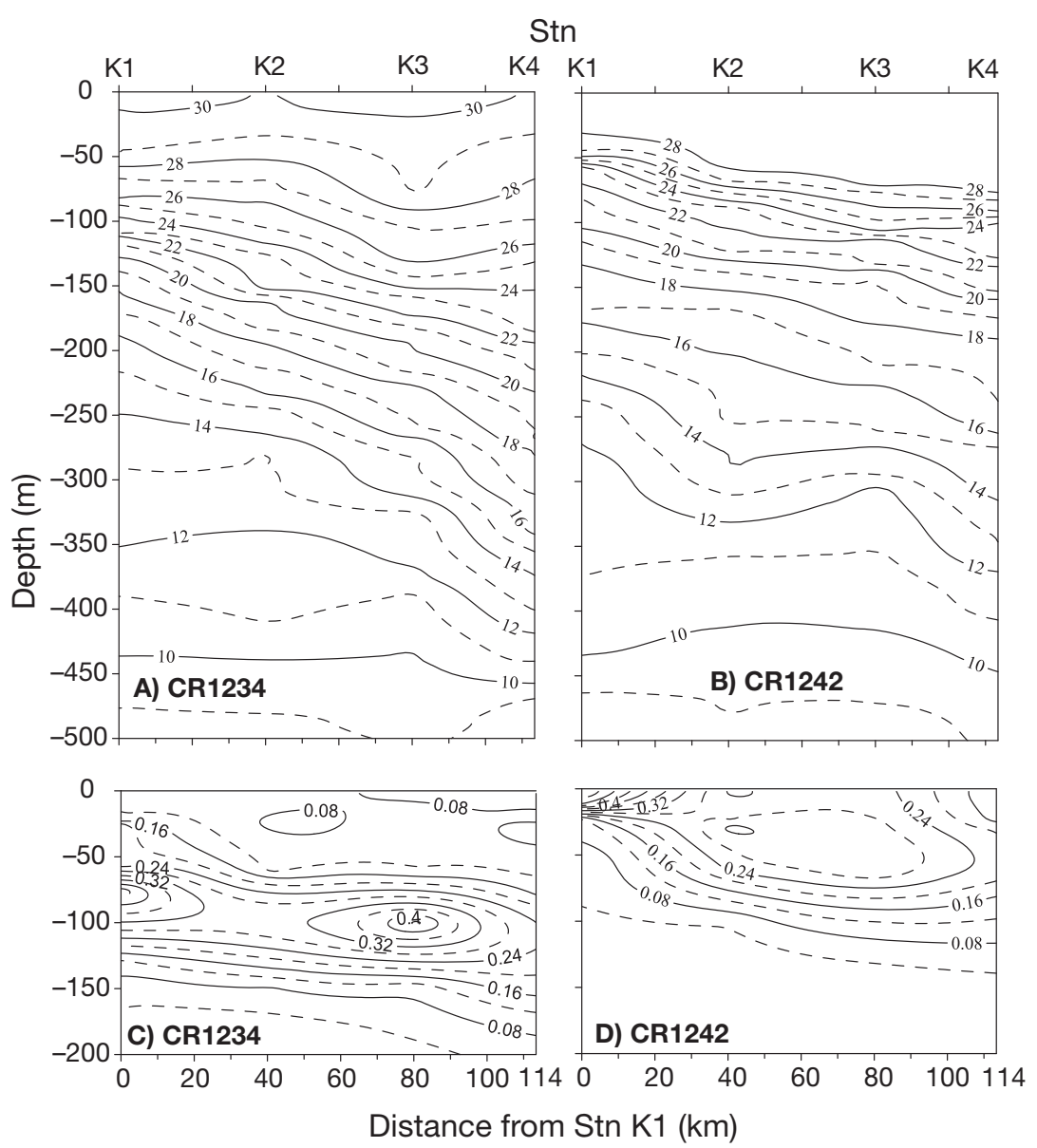

Fig. 3. Vertical profiles of $(\mathrm{A}, \mathrm{B})$ temperature $\left({ }^{\circ} \mathrm{C}\right)$ and $(\mathrm{C}, \mathrm{D}) \mathrm{chl}$ a concentration $\left(\mathrm{mg} \mathrm{m}^{-3}\right.$ ) at Transect $\mathrm{K}$ during the cruise before (CR1234) and after (CR1242) the typhoons post-typhoon analyses were also made on the absolute geostrophic velocities data collected on 10 July (Fig. 6A) and 25 August (Fig. 6B), respectively, covering the flow field of the northern Luzon Strait from AVISO. The subtidal current velocities measured by SbADCP (Fig. 5) were faster than the altimetry-derived geostrophic velocities (Fig. 6), but both shared a common qualitative flow pattern along the cruise tracks. This suggests that before the typhoons, the northward-flowing Kuroshio followed a relatively straight path in the Luzon Strait between 121 and $122^{\circ} \mathrm{E}$ (Fig. 6A), but as the typhoons passed, vigorous wind stresses exerted significant effects on currents in the upper ocean. The flow of the Kuroshio may have curved westward to the western reaches of the Luzon Strait between 119 and $120^{\circ} \mathrm{E}$ and may have been deflected northeastward after leaving the southeastern Taiwan Strait around the southern tip of Taiwan (Fig. 6B). That flow pattern suggests that a large volume of cold and less-saline water from the northern SCS and the southwestern coast of Taiwan could have been carried by the west flank of the looped
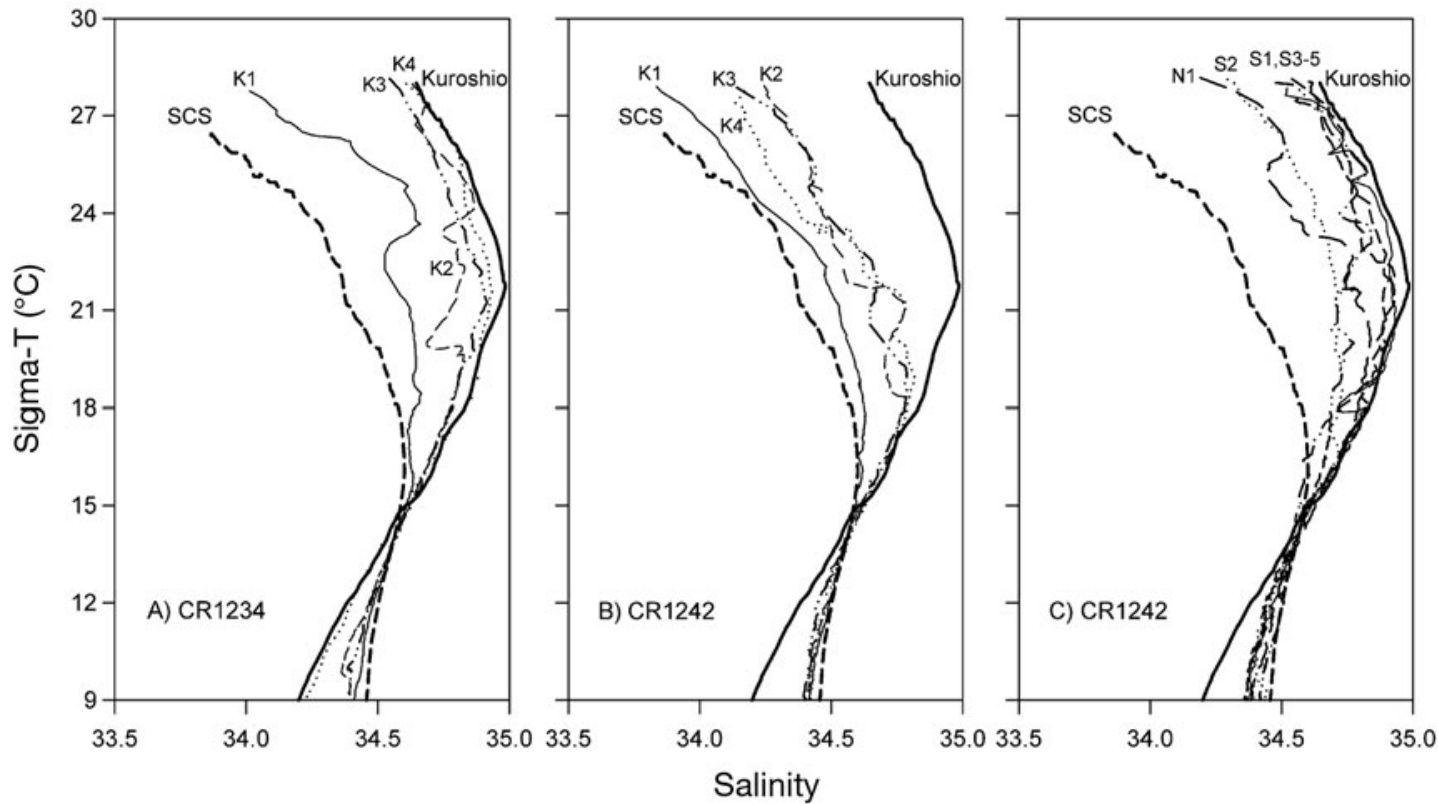

Fig. 4. Temperature versus salinity diagram for stations on Transect K in the Kuroshio Current (A) before and (B) after the typhoons, and (C) for stations south and north of Transect K after the typhoons. SCS: South China Sea 
A) CR1234
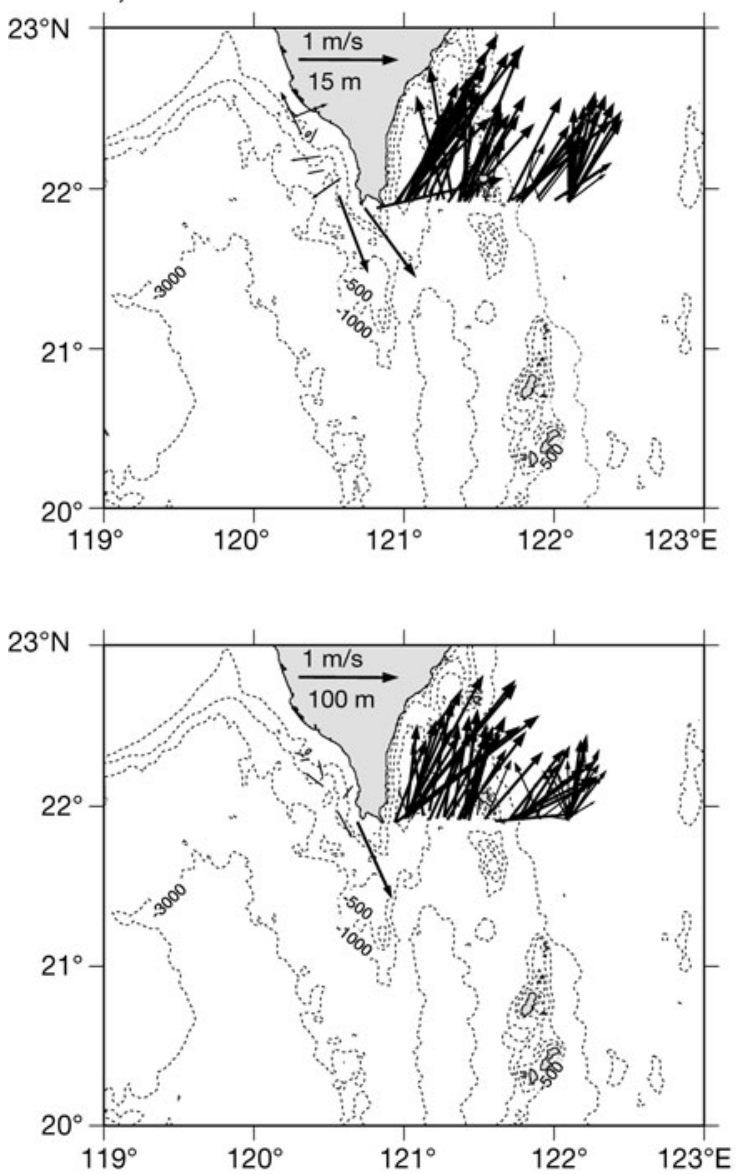

B) CR1242
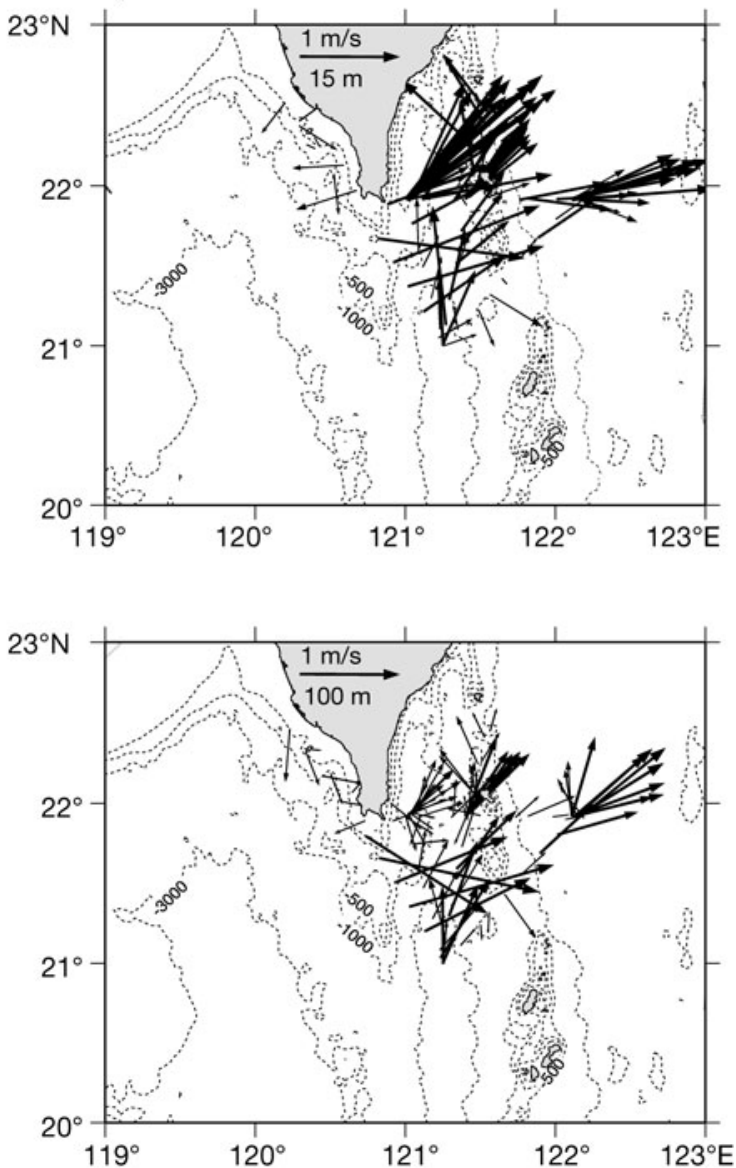

Fig. 5. Current velocities recorded by the shipboard acoustic Doppler current profiler (Sb-ADCP) at (upper panels) $15 \mathrm{~m}$ and (lower panels) $100 \mathrm{~m}$ depths (A) before and (B) after the typhoons. The high-frequency tidal currents have been subtracted from the raw $\mathrm{Sb}-\mathrm{ADCP}$ data

A) 10 July 2007

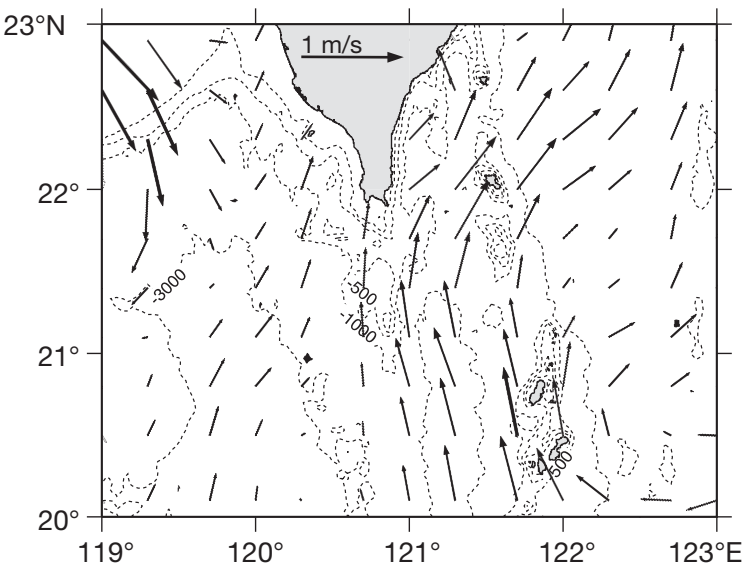

B) 25 August 2007

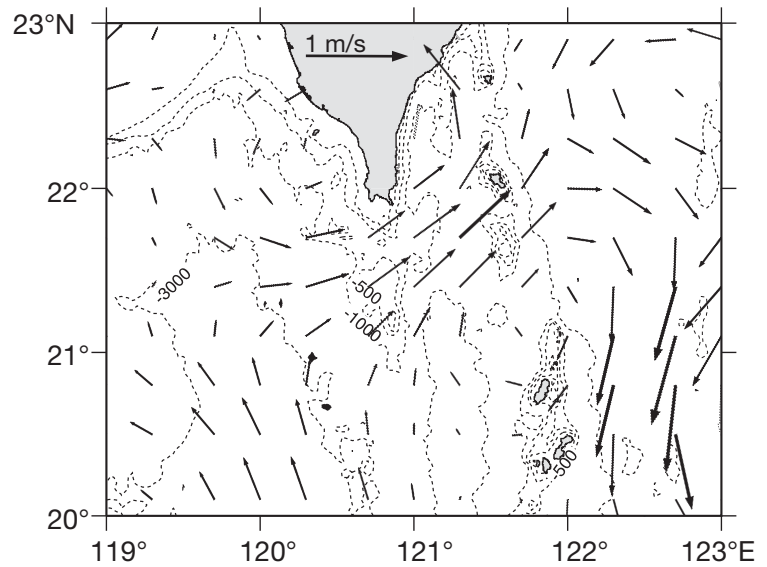

Fig. 6. Satellite altimeter data-derived absolute geostrophic flows for (A) 10 July (representing pre-typhoon conditions) and (B) 25 August (post-typhoon conditions) from the Archiving, Validation and Interpretation of Satellite Oceanographic data (AVISO) database 


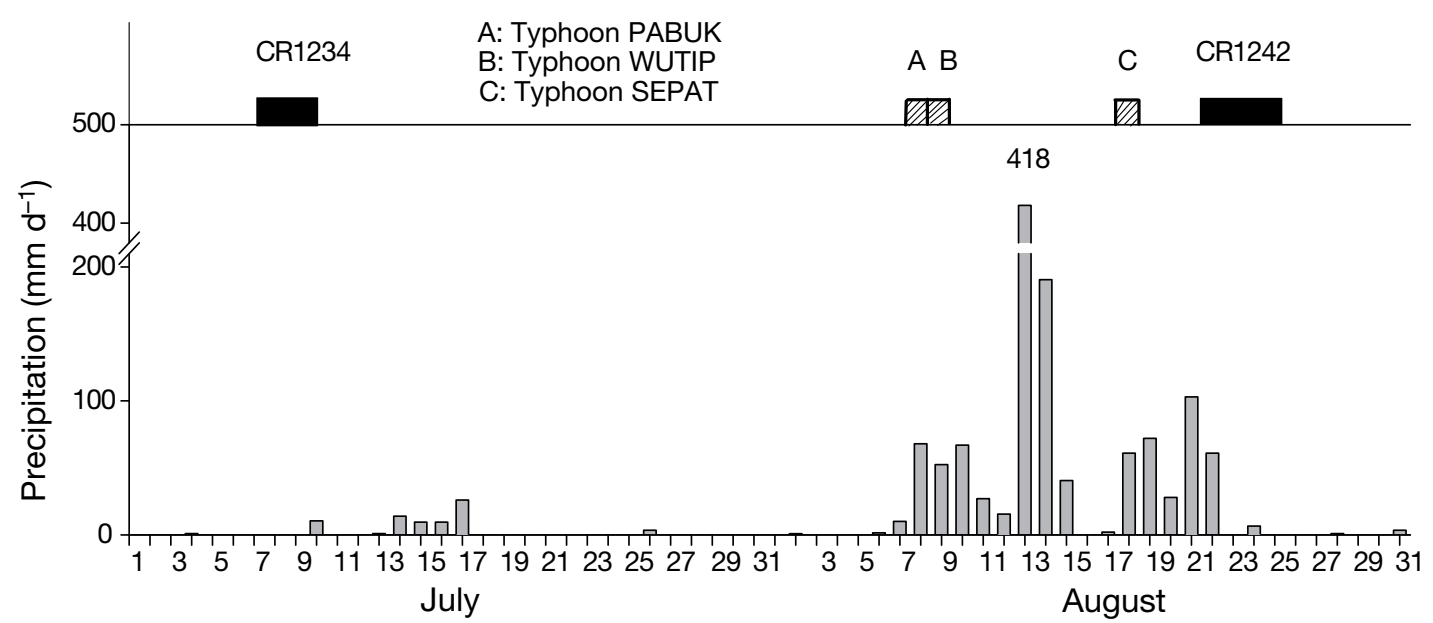

Fig. 7. Precipitation statistics for southern Taiwan in July and August 2007 (from the Kaohsiung weather station). Bars at top mark periods of typhoons and cruises
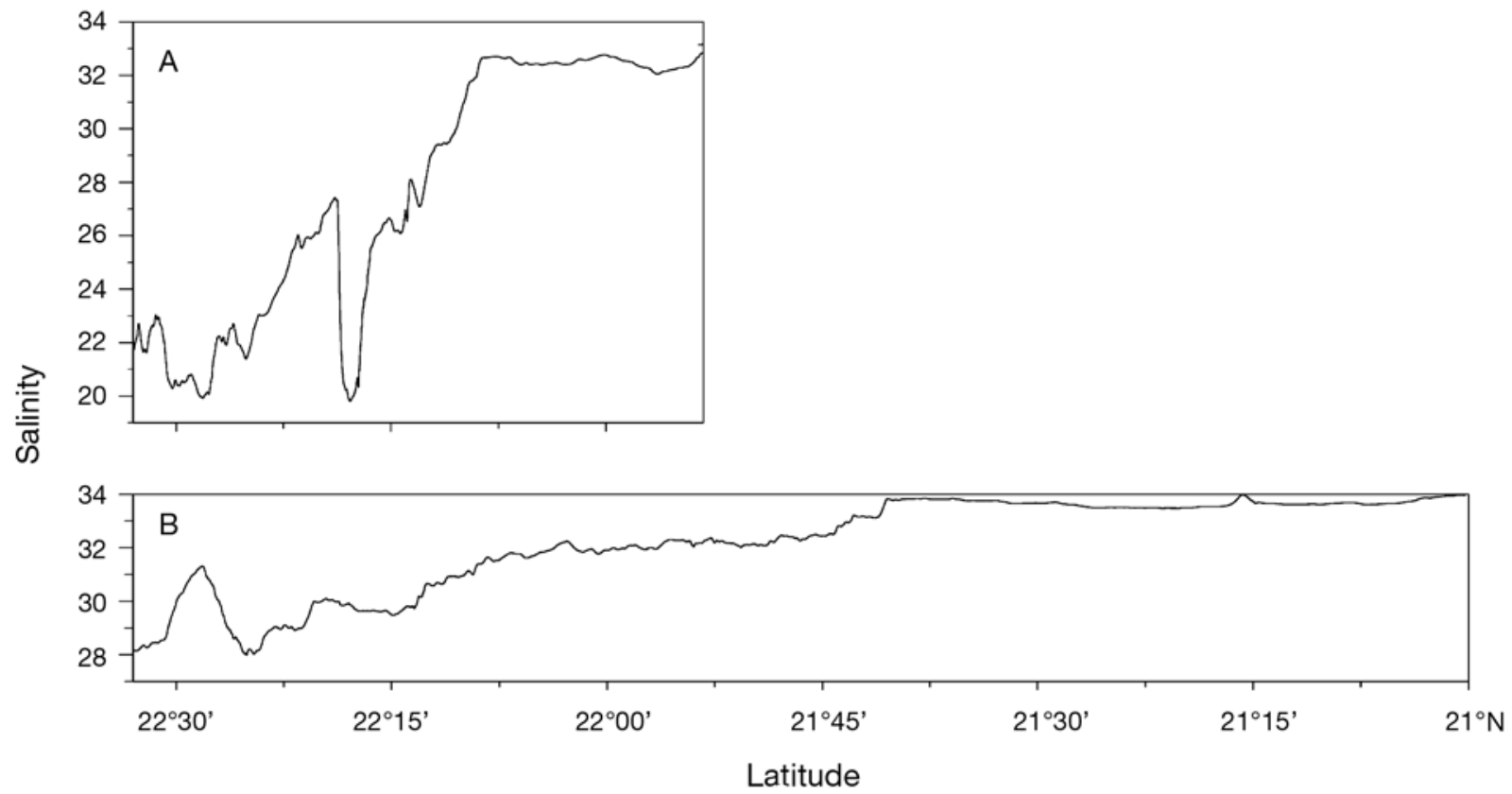

Fig. 8. Ship-track surface salinity recorded off the west coast of Taiwan between $21^{\circ} \mathrm{N}$ and $22^{\circ} 30^{\prime} \mathrm{N}$ on (A) 21 August and (B) 25 August, 2007

Kuroshio Current off southeastern Taiwan. Results from the ADCP data support this inferred source of the low-temperature and less-saline water in the surface waters of the upstream Kuroshio observed after the typhoons.

\section{Source of the less-saline water}

The less-saline northern SCS water could have originated from Taiwan's numerous SMRs. Increased river discharge from intense precipitation from typhoons often floods into coastal waters in the Taiwan Strait. Heavy rainfall was recorded (Fig. 7) by the Kaohsiung weather station $\left(22^{\circ} 37^{\prime} \mathrm{N}, 120^{\circ} 20^{\prime} \mathrm{E}\right)$ during much of August 2007, when the 3 typhoons hit Taiwan and later when CR1242 was conducted. No rainfall was observed for a long period before and during CR1234.

Salinity distribution recorded along the ship tracks indicates that surface salinity increased southwards in the southern Taiwan Strait (Fig. 8A). The lowest shiptrack surface salinity of 19.8 was detected on 21 August at the mouth of the Kaoping River at $22.6^{\circ} \mathrm{N}$. Salinity increased to 27 at $22^{\circ} \mathrm{N}$, and to 33 in the north- 

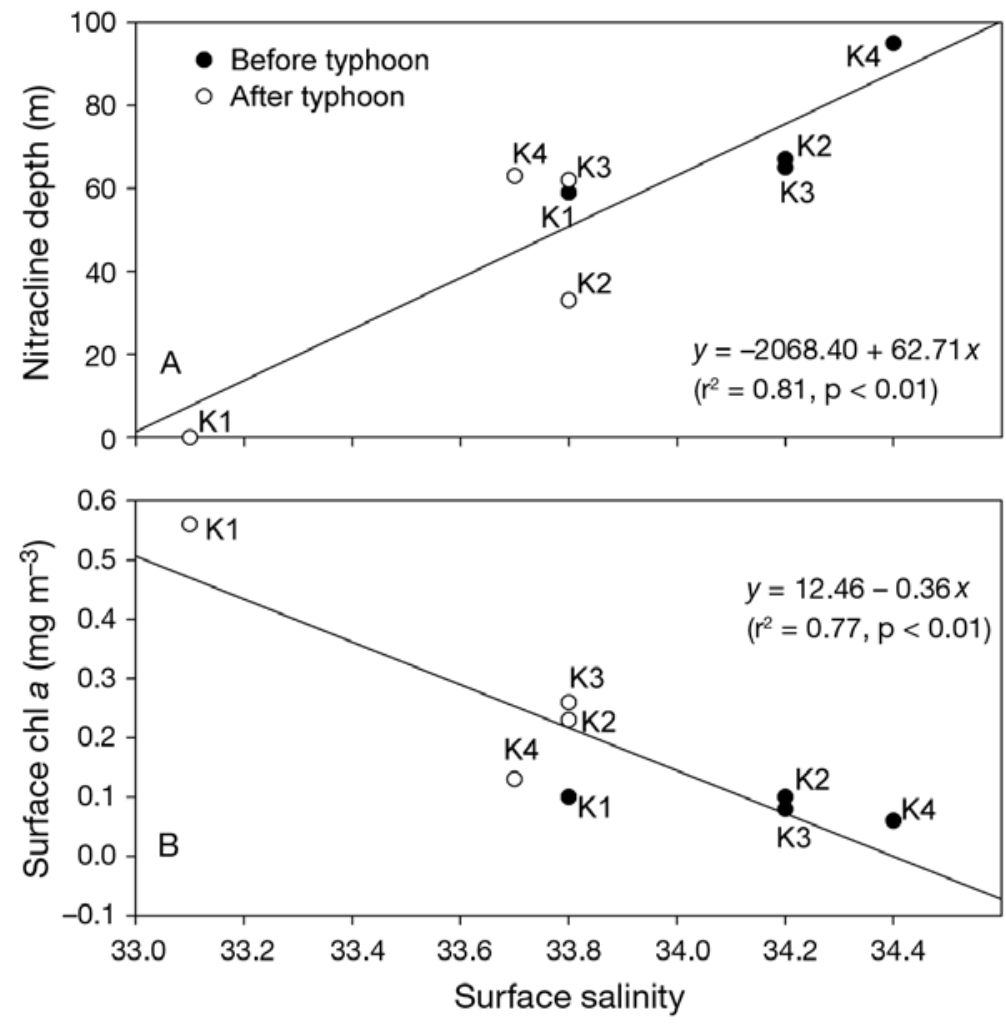

Fig. 9. Relationships between (A) nitracline depth and surface salinity and (B) surface chl a concentration and surface salinity at Stns K1 to K4 in the Kuroshio Current

ern Luzon Strait before reaching the Kuroshio region. By 25 August, surface salinity measured at the Kaoping River mouth was 27 (Fig. 8B). The rainfall and the ship-track salinity data support the assertion that riverine water reached the Kuroshio region.

\section{Distribution of nutrients}

After the typhoons, surface Kuroshio water became less saline and more rich in nutrients (Fig. 2). Among the 4 stations surveyed, surface $\mathrm{N}+\mathrm{N}$ and SRP at Stn K1 were significantly greater after the typhoons (390 and $45 \mathrm{nM}$, respectively) than before (both $13 \mathrm{nM}$ ) (Table 1). The nutrient enrichment was less obvious further offshore at Stns K2 to K4. The nitracline, which was shallower inshore than offshore (Table 1), shoaled from $72 \mathrm{~m}$ before to $40 \mathrm{~m}$ after the typhoons. Surface $\mathrm{N}+\mathrm{N}$ was negatively correlated with surface salinity $(\mathrm{r}=-0.82, \mathrm{p}<0.05)$. The depth of nitracline was thus significantly positively related to surface salinity according to the linear regression equation: Nitracline depth $=-2068.40+62.71$ Salinity $\left(\mathrm{R}^{2}=0.81, \mathrm{p}<0.01\right.$; Fig. 9A). $D_{\text {eu }}$ shoaled from 130 to $55 \mathrm{~m}$ (Table 1) at Stn K1 but not the other stations (127 to $142 \mathrm{~m}$ ).

\section{Phytoplankton biomass and productivity}

Surface chl a concentrations in the upstream Kuroshio (Table 1) averaged 3fold higher after the typhoons $(0.30 \mathrm{mg}$ $\left.\mathrm{m}^{-3}\right)$ than before $\left(0.09 \mathrm{mg} \mathrm{m}^{-3}\right)$. The increment was greater inshore than offshore along Transect K. Surface chl a concentration $\left(\mathrm{mg} \mathrm{m}^{-3}\right)$ was negatively related to surface salinity. The regression equation was chl $a=12.46-0.36$ Salinity $\left(R^{2}=0.77\right.$, $\mathrm{p}<0.01$; Fig. 9B). The chl a maximum shoaled (Fig. 3C,D) from an average of $103 \mathrm{~m}$ pre-typhoon to $38 \mathrm{~m}$ post-typhoon (Table 1). Water column integrated chl a (IChl), however, was slightly lower after the typhoons (22.6 $\mathrm{mg} \mathrm{m}^{-2}$ ) than before $\left(27.9 \mathrm{mg} \mathrm{m}^{-2}\right.$ ) (Table 1). Average surface PP was 4.4-fold higher after the typhoons (34.6 $\mathrm{mg} \mathrm{C} \mathrm{m}^{-3} \mathrm{~d}^{-1}$ ) than before (7.8 $\mathrm{mg} \mathrm{C}$ $\mathrm{m}^{-3} \mathrm{~d}^{-1}$ ) (Table 2). If we exclude the results of Stn K2, for which PP was not measured, it was 5.6-fold higher after the typhoons than before (43.8 vs. $7.8 \mathrm{mg} \mathrm{C} \mathrm{m} \mathrm{C} \mathrm{d}^{-1}$, respectively; Table 2). Surface PP (mg C $\mathrm{m}^{-3} \mathrm{~d}^{-1}$ ) was positively related to surface $\mathrm{N}+\mathrm{N}$ according to the regression equation: $\mathrm{PP}=4.99+180.29 \mathrm{~N}+\mathrm{N}\left(\mathrm{R}^{2}=0.99, \mathrm{p}<0.01\right.$; Fig. 10A). IPP was 2.5 -fold higher after the typhoons $\left(0.83 \mathrm{~g} \mathrm{C} \mathrm{m}^{-2} \mathrm{~d}^{-1}\right)$ than before (0.34 $\left.\mathrm{g} \mathrm{C} \mathrm{m}^{-2} \mathrm{~d}^{-1}\right)$ at Stn K4. IPP at Stn K2 was the highest $\left(1.04 \mathrm{~g} \mathrm{C} \mathrm{m}^{-2} \mathrm{~d}^{-1}\right)$. By contrast, IPP at Stn $\mathrm{K} 1$ was the lowest in spite of it having the highest surface PP. The shallow post-typhoon $\mathrm{D}_{\text {eu }}$ of $55 \mathrm{~m}$ was probably the cause. Its averaged PP in the euphotic layer (IPP/D $\mathrm{D}_{\text {eu }}$ mg $\mathrm{C} \mathrm{m}^{-3} \mathrm{~d}^{-1}$ ) was the highest among all stations (Fig. 10C). IPP/D eu was negatively related to either surface salinity $(r=-0.90, \mathrm{p}<0.05)$ or depth of nitracline $(r=-0.92, p<0.05)$. The linear regression depicting the latter relationship is: IPP/Deu $=11.76-0.087$ Nitracline depth $\left(\mathrm{R}^{2}=0.84, \mathrm{p}<0.05\right.$; Fig. 10C).

The typhoons' effect on $\mathrm{NO}_{3}$-NP was similar to their effects on PP. Surface $\mathrm{NO}_{3}-\mathrm{NP}$ was 9-fold greater (11.9 $\mathrm{mg} \mathrm{C} \mathrm{m}^{-3} \mathrm{~d}^{-1}$ ) after the typhoons than before (1.3 $\mathrm{mg} \mathrm{C} \mathrm{m}^{-3} \mathrm{~d}^{-1}$ ). If Stn $\mathrm{K} 2$ is included, the average post-typhoon surface $\mathrm{NO}_{3}$-NP was $8.6 \mathrm{mg} \mathrm{C} \mathrm{m}^{-3} \mathrm{~d}^{-1}$ (Table 2). Surface $\mathrm{NO}_{3}-\mathrm{NP}$ was positively related to surface $\mathrm{N}+\mathrm{N}(\mathrm{r}=0.99, \mathrm{p}<0.01$; Fig. 10B). Post-typhoon $\mathrm{INO}_{3}-\mathrm{NP}$ averaged $0.35 \mathrm{~g} \mathrm{C} \mathrm{m}^{-2} \mathrm{~d}^{-1}$ (Table 2). $\mathrm{INO}_{3}-\mathrm{NP}$ at Stn $\mathrm{K} 4$ was 3 times higher $\left(0.23 \mathrm{~g} \mathrm{C} \mathrm{m}^{-2} \mathrm{~d}^{-1}\right)$ after the typhoons than before $\left(0.07 \mathrm{~g} \mathrm{C} \mathrm{m}^{-2} \mathrm{~d}^{-1}\right)$. Similar to IPP, $\mathrm{INO}_{3}-\mathrm{NP}$ after the typhoons was higher at Stn $\mathrm{K} 2$ $\left(0.61 \mathrm{~g} \mathrm{C} \mathrm{m}^{-2} \mathrm{~d}^{-1}\right)$, but lower at Stn $\mathrm{K} 1\left(0.20 \mathrm{~g} \mathrm{C} \mathrm{m}^{-2}\right.$ $\mathrm{d}^{-1}$ ), which could be attributed to the shallower $\mathrm{D}_{\mathrm{eu}}$ after the typhoons. $\mathrm{INO}_{3}-\mathrm{NP} / \mathrm{D}_{\text {eu }}$ at Stn K1 was never- 
Table 2. Surface primary production (PP) and nitrate-uptake-based new production $\left(\mathrm{NO}_{3}-\mathrm{NP}\right)$, and water-column-integrated PP (IPP) and $\mathrm{NO}_{3}-\mathrm{NP}\left(\mathrm{INO}_{3}-\mathrm{NP}\right)$, as well as the ratio of $\mathrm{INO}_{3}$-NP to IPP at Stns K1, K2, and $\mathrm{K} 4$ before and after the typhoons; production at Stn K2 before typhoons were not measured because of limited ship time

\begin{tabular}{|c|c|c|c|c|c|}
\hline Stn & \multicolumn{2}{|c|}{$\begin{array}{l}\mathrm{PP} \\
\left(\mathrm{mg} \mathrm{C} \mathrm{m}^{-3} \mathrm{~d}^{-1}\right)\end{array}$} & \multicolumn{2}{|c|}{$\left(\mathrm{g} \mathrm{C} \mathrm{m}^{-2} \mathrm{~d}^{-1}\right)$} & $\begin{array}{l}\mathrm{INO}_{3}-\mathrm{NP}: \\
\text { IPP }\end{array}$ \\
\hline \multicolumn{6}{|c|}{ Before typhoons } \\
\hline K1 & 7.6 & 1.6 & 1.17 & 0.43 & 0.37 \\
\hline K4 & 8.0 & 1.0 & 0.34 & 0.07 & 0.20 \\
\hline Mean $\pm \mathrm{SE}$ & $7.8 \pm 0.2$ & $1.3 \pm 0.3$ & $0.76 \pm 0.42$ & $0.25 \pm 0.18$ & $0.29 \pm 0.09$ \\
\hline \multicolumn{6}{|c|}{ After typhoons } \\
\hline K1 & 75.9 & 19.0 & 0.63 & 0.20 & 0.32 \\
\hline $\mathrm{K} 2$ & 16.2 & 2.0 & 1.04 & 0.61 & 0.59 \\
\hline $\mathrm{K} 4$ & 11.7 & 4.9 & 0.83 & 0.23 & 0.28 \\
\hline Mean $\pm \mathrm{SE}$ & $34.6 \pm 20.7$ & $8.6 \pm 5.3$ & $0.83 \pm 0.12$ & $0.35 \pm 0.13$ & $0.40 \pm 0.10$ \\
\hline
\end{tabular}

were drastically reduced (Table 3), Trichodesmium spp. from $27.6 \times 10^{6}$ to $9.7 \times 10^{6}$ trichomes $\mathrm{m}^{-2}$ and $R$. intracellularis from $2.8 \times 10^{6}$ to $0.8 \times 10^{6}$ heterocysts $\mathrm{m}^{-2}$. The diatoms to which $R$. intracellularis symbiosed also changed from an assemblage of Hemiaulus spp. (39.3\%), Chaetoceros spp. (29.9\%), Rhizosolenia spp. (13.1\%), Bacteriastrum spp. (7.6\%), and Guinardiasp. (4.4\%) to one dominated by Hemiaulus spp. (88.9\%), Guinardia sp. $(4.8 \%)$, and Chaetoceros spp. $(4.6 \%)$. Cell densities of potential unicellular diazotrophic cyanobacteria in the surface water were also markedly lower after the typhoons, from 4307 to $899 \mathrm{l}^{-1}$ for the $2.5-5 \mu \mathrm{m}$ size fraction

theless lower than at Stn K2. Its upper $70 \mathrm{~m}$ water column $\mathrm{N}+\mathrm{N}$, unused by phytoplankton, remained high (Table 1). This low $\mathrm{INO}_{3}-\mathrm{NP} / \mathrm{D}_{\text {eu }}$ value renders an insignificant relationship $(\mathrm{p}=0.12)$ between $\mathrm{INO}_{3}$ NP/D $\mathrm{D}_{\text {eu }}$ and nitracline depth (Fig. 10D), which was unlike the significant relationship between IPP/D eu and nitracline depth (Fig. 10C).

The mean ratio of $\mathrm{INO}_{3}$-NP:IPP was greater after the typhoons than before (0.4 vs. 0.3 , respectively) (Table 2); however, the ratios differed by station. $\mathrm{INO}_{3}$-NP:IPP at Stn K4 was higher after (0.28) than before $(0.20)$ the typhoons (Table 2). After the typhoons, the highest $\mathrm{INO}_{3}$-NP:IPP occurred at Stn K2 (0.59). Although Stn K1 had highest surface $\mathrm{N}+\mathrm{N}$, its $\mathrm{INO}_{3}$ NP:IPP decreased from 0.37 to 0.32 (Table 2). At this station, as mentioned in the previous paragraph, the upper $70 \mathrm{~m}$ water column had a high abundance of $\mathrm{N}+\mathrm{N}$ (Table 1) that had not been used by phytoplankton.

\section{Phytoplankton assemblages}

After the typhoons, the phytoplankton community in the Kuroshio went from favoring diazotrophs to favoring diatoms, which reflected the changed nutrient status. Abundances of Trichodesmium spp. and Richelia intracellularis
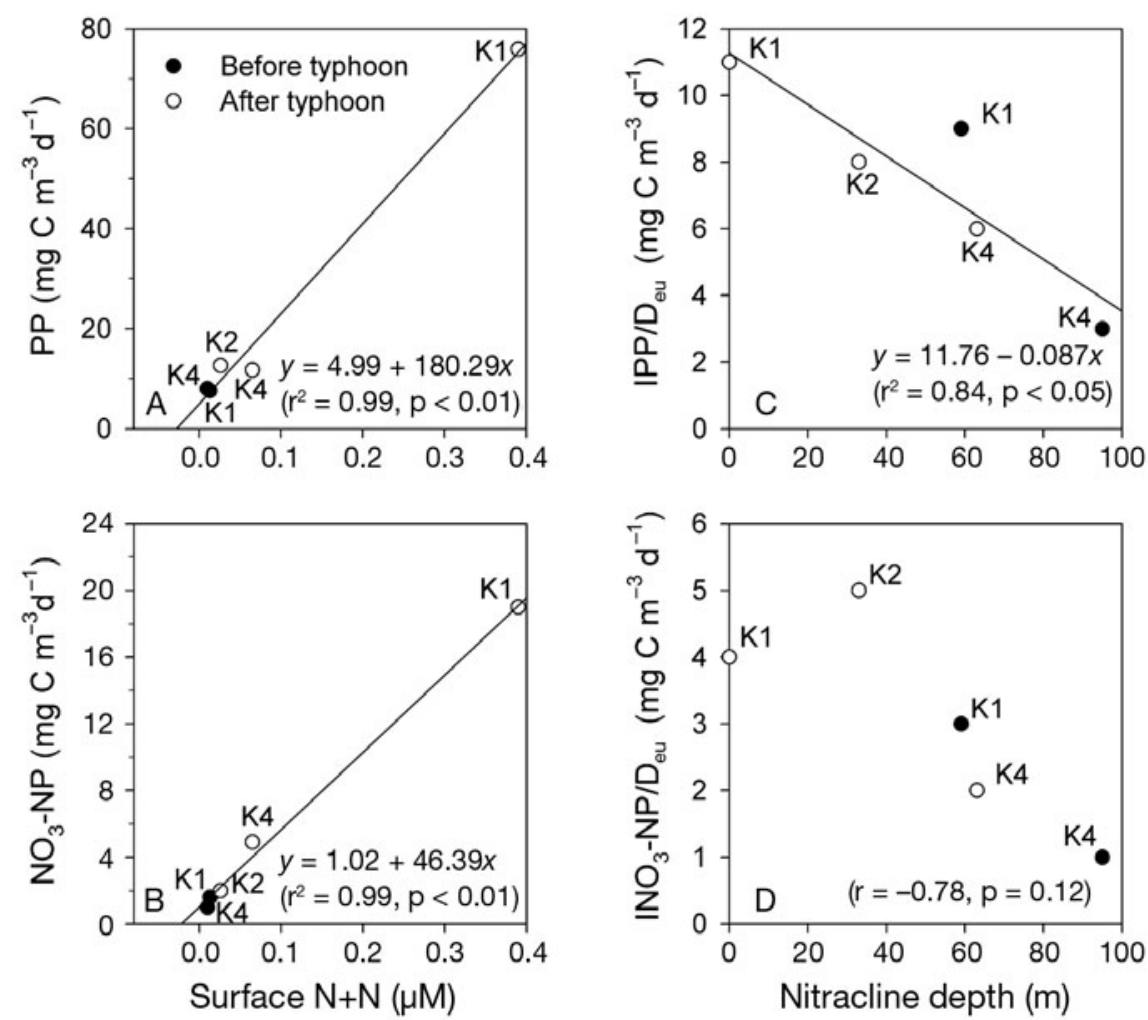

Fig. 10. Relationships between (A) surface primary production (PP) and surface nitrate plus nitrite $(\mathrm{N}+\mathrm{N})$ concentration; $(\mathrm{B})$ surface nitrate-uptake-based new production $\left(\mathrm{NO}_{3}-\mathrm{NP}\right)$ and surface $\mathrm{N}+\mathrm{N}_{i}(\mathrm{C})$ averaged PP in the euphotic layer (IPP/D $\left.\mathrm{D}_{\text {eu }}\right)$ and nitracline depth; and (D) averaged $\mathrm{NO}_{3}-\mathrm{NP}$ in the euphotic layer $\left(\mathrm{INO}_{3}-\mathrm{NP} / \mathrm{D}_{\text {eu }}\right)$ and nitracline depth. Measurements made before $(\bullet)$ and after $(0)$ the typhoons at Stns K1 to K4 
Table 3. Water-column-integrated abundances of Trichodesmium spp. and $R$. intracellularis and surface unicellular cyanobacteria densities at Stns K1 to K4 before and after the typhoons

\begin{tabular}{|c|c|c|}
\hline \multirow{2}{*}{$\begin{array}{l}\text { Phytoplankton } \\
\text { Stn }\end{array}$} & \multicolumn{2}{|c|}{ Abundance } \\
\hline & Before typhoons & After typhoons \\
\hline \multicolumn{3}{|c|}{ Trichodesmium sp. $\left(\times 10^{6}\right.$ trichomes $\left.\mathrm{m}^{-2}\right)$} \\
\hline K1 & 49.81 & 0.33 \\
\hline K2 & 26.63 & 18.69 \\
\hline K3 & 26.90 & 36.00 \\
\hline K4 & 7.09 & 0.65 \\
\hline Mean \pm SE & $27.6 \pm 8.7$ & $9.7 \pm 8.8$ \\
\hline \multicolumn{3}{|c|}{$R$. intracellularis $\left(\times 10^{6}\right.$ cells $\left.\mathrm{m}^{-2}\right)$} \\
\hline K1 & 4.60 & 0.20 \\
\hline K2 & 2.64 & 1.17 \\
\hline K3 & 3.52 & 1.47 \\
\hline K4 & 0.30 & 0.36 \\
\hline Mean \pm SE & $2.8 \pm 0.9$ & $0.8 \pm 0.3$ \\
\hline \multicolumn{3}{|c|}{ Unicellular cyanobacteria $\left(\times 10^{3}\right.$ cells $\left.\mathrm{m}^{-3}\right)$} \\
\hline \multicolumn{3}{|c|}{ Size $2.5-5 \mu \mathrm{m}$} \\
\hline K1 & 2518 & 303 \\
\hline $\mathrm{K} 2$ & 727 & 723 \\
\hline K3 & 4635 & 1183 \\
\hline K4 & 9348 & 1385 \\
\hline Mean \pm SE & $4307 \pm 1860$ & $899 \pm 242$ \\
\hline \multicolumn{3}{|l|}{ Size $5-10 \mu \mathrm{m}$} \\
\hline K1 & 147 & 0 \\
\hline K2 & 84 & 29 \\
\hline K3 & 215 & 4 \\
\hline K4 & 118 & 65 \\
\hline Mean $\pm \mathrm{SE}$ & $141 \pm 28$ & $25 \pm 15$ \\
\hline
\end{tabular}

phoons, from 110 to 377 cells l$^{-1}$ (Table 4 ). The pennate diatoms were 5 times more numerous after the typhoons, and centric diatoms were 1.5 times more numerous. The dominance of Nitzschia spp., Navicula spp., Pseudonitzschia spp., and Thalassionema spp. in the pennate diatom assemblage was unchanged. The centric diatoms showed no clear species dominance before the typhoons; 2 genera, Rhizosolenia and Asterionella, became more common after the typhoons. The cell density of coccolithophores was doubled at Stn K1 but was reduced by half at Stn K2 after the typhoons. While cell densities of Gephyrocapsa oceanica and Emiliania huxleyi were higher after the typhoons, those of oligotrophic species such as Umbellosphaera tenuis and Discosphaera tubifera were lower. Before the typhoons, the predominant species at Stn K1 was $U$. tenuis $(68.9 \%)$, and Gephyrocapsa oceanica $(44.2 \%)$ and $U$. tenuis $(25.8 \%)$ were co-dominant at Stn K2. After the typhoons, Gephyrocapsa oceanica was the only dominant species at both Stn K2 (99\%) and Stn K1 $(64.0 \%)$. The second dominant species at Stn K2 was E. huxleyi $(11.9 \%)$. The picophytoplankton community was also changed; cell densities of Prochlorococcus sp. averaged $21.3 \times 10^{12}$ cells $\mathrm{m}^{-2}$ before the typhoons but
Table 4. Cell density of diatoms in the surface water at Stns K1 to K4 before and after the typhoons

\begin{tabular}{|c|c|c|}
\hline \multirow{2}{*}{$\begin{array}{l}\text { Diatoms } \\
\text { Stn }\end{array}$} & \multicolumn{2}{|c|}{ Density (cells $\mathrm{l}^{-1}$ ) } \\
\hline & Before typhoons & After typhoons \\
\hline \multicolumn{3}{|l|}{ Total } \\
\hline $\mathrm{K} 1$ & 49 & 392 \\
\hline $\mathrm{K} 2$ & 275 & 247 \\
\hline K3 & 59 & 693 \\
\hline K4 & 56 & 178 \\
\hline Mean \pm SE & $110 \pm 55$ & $377 \pm 114$ \\
\hline \multicolumn{3}{|l|}{ Centric } \\
\hline K1 & 4 & 57 \\
\hline K2 & 118 & 45 \\
\hline K3 & 35 & 111 \\
\hline K4 & 35 & 70 \\
\hline Mean \pm SE & $48 \pm 25$ & $71 \pm 15$ \\
\hline \multicolumn{3}{|l|}{ Pennate } \\
\hline K1 & 45 & 335 \\
\hline K2 & 157 & 202 \\
\hline K3 & 24 & 582 \\
\hline K4 & 21 & 108 \\
\hline Mean \pm SE & $62 \pm 32$ & $307 \pm 103$ \\
\hline
\end{tabular}

Table 5. Prochlorococcus sp. and Synechococcus spp. Upper $200 \mathrm{~m}$ integrated cell densities at Stns K1 to K4 before and after the typhoons

\begin{tabular}{|c|c|c|}
\hline \multirow{2}{*}{$\begin{array}{l}\text { Phytoplankton } \\
\text { Stn }\end{array}$} & \multicolumn{2}{|c|}{ Density } \\
\hline & Before typhoons & After typhoons \\
\hline \multicolumn{3}{|c|}{ Prochlorococcus sp. $\left(\times 10^{12}\right.$ cells $\left.\mathrm{m}^{-2}\right)$} \\
\hline K1 & 18.9 & 3.5 \\
\hline K2 & 23.3 & 9.7 \\
\hline K3 & 20.3 & 11.5 \\
\hline K4 & 22.8 & 7.0 \\
\hline Mean \pm SE & $21.3 \pm 1.0$ & $7.9 \pm 1.7$ \\
\hline \multicolumn{3}{|c|}{ Synechococcus spp. $\left(\times 10^{11}\right.$ cells $\left.\mathrm{m}^{-2}\right)$} \\
\hline K1 & 11.4 & 5.0 \\
\hline $\mathrm{K} 2$ & 6.0 & 13.7 \\
\hline K3 & 10.8 & 21.1 \\
\hline K4 & 2.6 & 3.7 \\
\hline Mean \pm SE & $7.7 \pm 2.1$ & $10.9 \pm 4.1$ \\
\hline
\end{tabular}

only $7.9 \times 10^{12}$ cells m ${ }^{-2}$ after. Conversely, Synechococcus spp. cell densities increased from $0.77 \times 10^{12}$ cells $\mathrm{m}^{-2}$ to $1.1 \times 10^{12}$ cells m $\mathrm{m}^{-2}$ (Table 5).

\section{DISCUSSION}

\section{Changes in phytoplankton productivity and assemblages}

The in situ measurements in the upstream Kuroshio showed markedly higher phytoplankton productivities and surface nutrients after the typhoons. Surface chl a 
concentration as well as $\mathrm{NO}_{3}-\mathrm{NP}$ and $\mathrm{PP}$ all were enhanced after the typhoons. The values observed were not only higher after the typhoons than before, but also higher than the multiyear averages measured in the summer at the broader upstream Kuroshio region including northern Luzon Strait (Chen et al. 2008), with the values of PP being 1.6-fold higher and of $\mathrm{NO}_{3}$-NP 2.2-fold higher. Typically flourishing diazotrophs were quickly replaced by diatoms. The presence of less-saline water in the upper water column of the Kuroshio indicated that the main cause of the biogeochemical shift was mixing of surface water by riverine discharge rather than upwelling from the deep when the typhoons passed by. Interactions between ocean and river discharge are especially important in tropical and subtropical oceans such as Kuroshio that are mostly stratified and oligotrophic. While nitrogen input could be orders of magnitude greater than local input source, similar chl a enhancement from storminduced injection of the Mississippi River plume into the open Gulf of Mexico was revealed in a satellite study (Yuan et al. 2004). Although production or chl a enhancement derived from satellite imagery tends to be exaggerated because of increased abundance of dissolved organic matter in near-shore waters, our results by direct measurements, even in the surface water of the most near-shore Stn K1, showed consistent chl $a$ and production enhancements.

\section{Input of SCS surface water enhanced the phytoplankton productivity in the Kuroshio}

In the summer, surface SCS water spreads to nearshore Kuroshio off eastern Taiwan when the southwestern monsoon prevails (Chern \& Wang 1998). Before the typhoons, Stn K1 had a surface salinity of 33.8, implicating strongly its origin from the SCS, which has a lower surface salinity than the Kuroshio. IPP and INP at Stn K1 were higher than at the offshore Stn K4 that was not mixed by the surface SCS water. Chen et al. (2008) reported a mean IPP of $0.51 \mathrm{~g} \mathrm{C} \mathrm{m}^{-2}$ $\mathrm{d}^{-1}$ and $\mathrm{INO}_{3}-\mathrm{NO}_{3}-\mathrm{NP}$ of $0.16 \mathrm{~g} \mathrm{C} \mathrm{m}^{-2} \mathrm{~d}^{-1}$ in the upstream Kuroshio; IPP and $\mathrm{INO}_{3}$-NP measured in the present study at Stn K1 before the typhoons were at least 2-fold higher. After the typhoons, increments in phytoplankton biomass and productivity were even higher as the influx from surface SCS was stronger.

\section{Factors affecting biogeochemical changes after the typhoons}

In addition to enriching nutrients, a typhoon intensifies water turbulence and diminishes sunlight. These abrupt changes might affect phytoplankton growth quantitatively (best reflected by productivity) and qualitatively (by phytoplankton assemblages). Phytoplankton productivity at Stn K1 was likely limited by light, not by nutrients, because of the increased entrainment of nutrients and associated suspended particles, probably from riverine mixing. After the typhoons, watercolumn integrated productivity (IPP and $\mathrm{INO}_{3}-\mathrm{NP}$ ) at Stn K1 was only $50 \%$ of the pre-typhoon level. This reduction was probably due to reduced light availability in the water column for phytoplankton growth. The euphotic layer of Stn K1 was reduced from $>100 \mathrm{~m}$ to $55 \mathrm{~m}$ after the typhoons (Table 1). The discrepancy that Stn $\mathrm{K} 1$ had low IPP and $\mathrm{INO}_{3}-\mathrm{NP}$ but high IPP/ $\mathrm{D}_{\text {eu }}$ and low $\mathrm{INO}_{3}-\mathrm{NP} / \mathrm{D}_{\text {eu }}$ as shown in Fig. 10 could be explained by the presence of non-nitrate nitrogen such as $\mathrm{NH}_{4}$ that is usually preferred and readily used by phytoplankton (Dortch 1990). There were no measurements made of $\mathrm{NH}_{4}$ in the present study. A study conducted by Ning et al. (2001) in the estuary of the Kaoping River, the largest nitrogen source along southern Taiwan coast, reported an approximate $\mathrm{NH}_{4}$ concentration of $125 \mu \mathrm{M}$ in the dry season (February) and $7 \mu \mathrm{M}$ in the wet season (August). How much dilution would occur through the riverine mixing is not known. If riverine input is driving the production, the resulting PP from $\mathrm{NH}_{4}$ assimilation can therefore be considered to be 'new production'. This might then affect (underestimate) the significance of the new production estimate calculated using nitrate alone. The result at Stn K4 that the post-typhoon increase in IPP was far greater than that in $\mathrm{INO}_{3}$-NP (Table 2) might also be attributed to enhanced non-nitrate nitrogen assimilation after the typhoons. The presence of abundant $\mathrm{N}+\mathrm{N}$ in the upper $70 \mathrm{~m}$ water column after the typhoons (Table 1) indicates strongly that nitrogen did not limit phytoplankton growth.

Storm-caused shoaling of the euphotic layer has an important implication for satellite imagery estimates of PP. Lin et al. (2003) used satellite imagery to estimate the effects of a typhoon on IPP in the SCS. Their IPP was estimated using 3 variables (surface water chl a concentration, temperature, and PAR) that were generated from satellite images. They used a 7-order polynomial relationship between maximum carbon fixation rate within a water column and temperature, developed by Behrenfeld \& Falkowski (1997), to calculate IPP. Our results suggest, however, that their IPP estimates could deviate greatly from in situ direct measurements if their study had been conducted in waters prone to riverine mixing. The surface temperatures we measured along Transect $\mathrm{K}$ were up to $30.3^{\circ} \mathrm{C}$, which is higher than the temperature range $\left(-1\right.$ to $\left.29^{\circ} \mathrm{C}\right)$ applied to the equation of Behrenfeld \& Falkowski (1997); however, the maximum carbon fixation rate in their equa- 
tion increased as temperature decreased between 29 and $20^{\circ} \mathrm{C}$. If we assume that surface PAR at Stn K1 was the same before and after the typhoons, and ignore the effect of temperature difference, with a surface chl a concentration after the typhoon as high as $0.56 \mathrm{mg} \mathrm{m}^{-3}$, then the model would predict an IPP at least 5.6-fold higher than that from before the typhoons when chl a was $0.10 \mathrm{mg} \mathrm{m}^{-3}$. In fact, our in situ measurements of IPP revealed a $50 \%$ reduction instead. This example clearly demonstrates the need for caution when satellite images are used in estimating IPP from chl a concentration in waters influenced by terrestrial influx.

Population abundance of Trichodesmium spp. decreased after the typhoons at most stations. The windinduced mixing from the passing typhoons was not a likely cause. Although calm water with low turbulence encourages aggregation of Trichodesmium spp. trichomes and tends to enhance $\mathrm{N}_{2}$ fixation (Carpenter \& Price 1976), hurricane-forced mixing does not affect adversely colony abundance of Trichodesmium spp. (Davis \& McGillicuddy 2006). Nutrient entrainment and possibly light limitation, on the other hand, could hinder the growth of Trichodesmium spp. This is best supported by our observations that abundance of Trichodesmium spp. decreased the most at Stn K1, instead of Stn K4. If we assume that strong wind and water mixing would decrease Trichodesmium spp. abundance, then Stn K4, which was located closest to the typhoon trajectory, would have been affected most adversely. Instead, $>99 \%$ of the Trichodesmium spp. trichomes were lost at Stn K1, which was the most distant station from the typhoons' paths. Stn K1 had the highest surface $\mathrm{N}+\mathrm{N}$ and shallowest Deu among all the stations.

In the open ocean, Trichodesmium spp. are inferior competitors for uptaking nitrate compared to other fast-growing phytoplankton. Abundance of Trichodesmium spp. and PP were found to be inversely correlated at Stn ALOHA in the subtropical North Pacific Ocean (Letelier \& Karl 1996). Trichodesmium spp. can utilize various forms of fixed nitrogen, including ammonium, urea, and nitrate. Nitrate, with uptake rates comparatively low, is considered a poor nitrogen source for their natural populations in oligotrophic seas (Mulholland et al. 1999). Because Trichodesmium spp. are easily susceptible to iron limitation or deficiency, they cannot compete with the faster-growing nondiazotrophs when and where nitrate is abundant. Nondiazotrophs use nitrate more efficiently and take up iron at concentrations only 1 to $40 \%$ of that needed by diazotrophs (Raven 1988, Kustka et al. 2003). In contrast to Trichodesmium spp., diatoms in the Kuroshio flourished after the typhoons. Son et al. (2007) inferred the dominance of diatoms in the Northwest Atlantic after Hurricane Fabian from bio-optical algorithms, which was not validated with in situ measurement.
The present study provides concrete evidence that confirms the marked shift in the phytoplankton community after a typhoon. Light limitation in the water column might also be a reason for the reduction of post-typhoon Trichodesmium spp. abundance. $\mathrm{N}_{2}$ fixation depends on energy from photosynthesis. Nitrogen fixation rates of Trichodesmium spp. are lower for cells collected from deep waters than from surface waters and for cells incubated at lower light levels (Letelier \& Karl 1998).

Nutrient enrichment may be another reason for the change of dominant coccolithophore species after the typhoons. As cell densities of extremely oligotrophic species such as Umbellosphaera tenuis and Discosphaera tubifera decreased, densities of Gephyrocapsa oceanica and Emiliania huxleyi increased. Umbellosphaera spp. (U. irregularis and U. tenuis) and $D$. tubifera, which are endemic in tropical or subtropical waters, usually dominate the coccolithophore community in the warm season (McIntyre et al. 1970). E. huxleyi out-competes other coccolithophores (Brand 1994) whenever and wherever surface nitrate becomes available, and tends to remain dominant almost constantly, especially during cold months. In the SCS, E. huxleyi and $G$. oceanica are dominant in the winter when upper water column nutrients are relatively high due to strong mixing. In contrast, $U$. tenuis and $U$. irregularis thrive in the summer, when the upper water column is stratified and poor in nutrients (Chen et al. 2007). The supply of nutrients also could be linked to the post-typhoon change of dominance in the picophytoplankton community from Prochlorococcus sp. to Synechococcus spp. Unlike Prochlorococcus sp., Synechococcus spp. use nitrate efficiently, in addition to $\mathrm{NH}_{4}{ }^{+}$and urea (Moore et al. 2002). They were found to bloom during deep mixing in the Sargasso Sea (DuRand et al. 2001) and the Red Sea (Lindell \& Post 1995) because of nutrient entrainment. In the Sargasso Sea, a bloom of Synechococcus spp. has been attributed to episodic nanomolar changes of available nitrate (Glover et al. 1988).

\section{Surface nutrient enrichment and coastal water entrainment}

The extent of the less-saline surface water over Transect $\mathrm{K}$ after the typhoons indicated how and where the Kuroshio was mixed by surface SCS waters. The lesssaline waters of SCS origin came from the southern Taiwan Strait, more precisely, the coast off southwestern Taiwan. Mean surface salinity in the northern SCS basin is 34.0 in summer (Chen \& Chen 2006). The surface salinity of Stn K1 after the typhoons was 33.1, indicating a proximate source of less-saline water mass. Salinity 
distribution recorded along the ship track indicates that surface salinity dropped to as low as 19.8 at $22.6^{\circ} \mathrm{N}$ and increased southwards to 27 at $22^{\circ} \mathrm{N}$ in the southern Taiwan Strait (Fig. 7). The SMRs in eastern Taiwan, facing the Kuroshio, are generally very small, and discharge at the north side of Transect K. As surface flows near Stn K1 were strongly northward (Fig. 5), any significant influence from these SMRs was unlikely. The larger SMRs in western Taiwan that discharge into the Taiwan Strait are thus the more likely source of freshwater that diluted widely the waters off southern Taiwan, including the Kuroshio, after the typhoons.

The patterns of nutrient distribution and light attenuation in the Kuroshio also support this idea. After the typhoons, the entrainment of the nutrient-laden riverine water revealed a high surface $\mathrm{N}+\mathrm{N}(390 \mathrm{nM})$ at Stn K1, which is much higher than the mean summertime $\mathrm{N}+\mathrm{N}$ of $13 \mathrm{nM}$ in the SCS basin (Chen \& Chen 2006). The sediment particles loaded in the riverine water brought about a shallow euphotic layer at Stn K1. The biogeochemical effects of the entrained riverine water could be far-reaching. In addition to biological particles, lithogenic and nonlithogenic particles (Liu et al. 2006), as well as anthropogenic pollutants, such as polycyclic aromatic hydrocarbons (Fang et al. 2009) that are present in the riverine water could be transported downstream to the shelf of the East China Sea and even to Japan as the Kuroshio flows north.

\section{Unlikely importance of typhoon wind-induced upwelling on nutrient enrichment}

Although low temperatures occurred post-typhoon in the upper $400 \mathrm{~m}$ of the Kuroshio, they were not necessarily caused by wind-induced upwelling from the typhoons. The velocity of upwelling was calculated from the Ekman pumping velocity (Gill 1982), which is defined as $\mathrm{w}_{\mathrm{E}}=(\nabla \times \tau) /(\rho f)$, where $\nabla=\partial / \mathrm{x} i+\partial / \partial_{y j} \tau$ is wind stress, $\rho$ is a reference density of seawater $(=1025$ $\mathrm{kg} \mathrm{m}^{-3}$ ), and $f$ is the Coriolis parameter. Because $f$ at $21^{\circ} \mathrm{N}$ is $5.21 \times 10^{-5} \mathrm{~s}^{-1}$ and $\nabla \times \tau$ is approximately 5.34 $\times 10^{-5} \mathrm{~N} \mathrm{~m}^{-3}$, the corresponding Ekman pumping velocity in the Kuroshio is around $86 \mathrm{~m} \mathrm{~d}^{-1}$. This upwelling velocity, assuming a storm force period of $0.5 \mathrm{~d}$, would cause a vertical displacement of $\sim 50 \mathrm{~m}$ near the typhoon center. Fig. 11 further shows spatial variation of the Ekman pumping velocity-induced Ekman depth. The Ekman depth was calculated as (Ekman pumping velocity) $\times$ (storm force period), where Ekman pumping velocity was calculated using wind speed measured by satellite scatterometer (QuikSCAT) on 17 August 2007 and storm force period was 0.5 d. Fig. 11 suggests the Ekman depth caused by Typhoon Sepat was generally $<10 \mathrm{~m}$ at Stns K1 to K4.

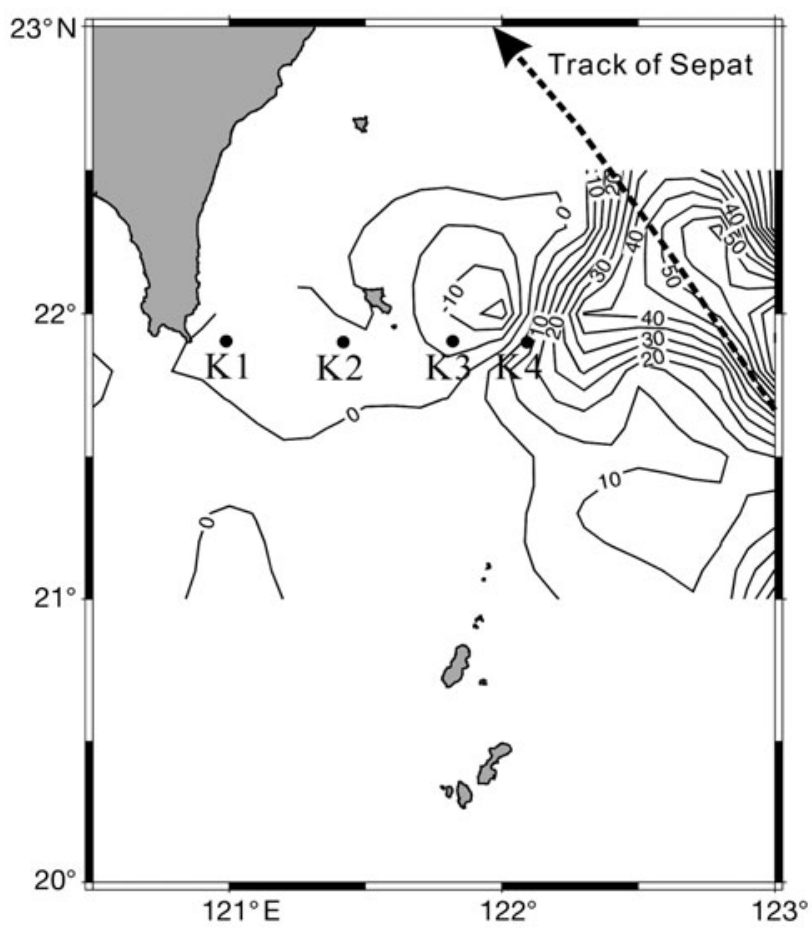

Fig. 11. Spatial variation of the Ekman pumping velocityinduced Ekman depth $(\mathrm{m})$ calculated using wind speed. Wind speed was measured by satellite scatterometer (QuikSCAT) on 17 August when Typhoon Sepat was passing through the Kuroshio region along the coast of East Taiwan

It was thus unlikely that the typhoon wind-induced upwelling contributed significantly to the nutrient enrichment observed at Stns K1 to K4. In addition, our post-typhoon survey was conducted 5 to $10 \mathrm{~d}$ after Typhoon Sepat passed. With the surface current flowing at $100 \mathrm{~cm} \mathrm{~s}^{-1}$ (Liang et al. 2003), any biogeochemical reaction associated with upwelling would only occur 430 to $860 \mathrm{~km}$ downstream, almost near the East China Sea shelf or further north. The cool water mass that appeared post-typhoon in the surface at Stns K1 to K4 was most probably the spread of SCS water. In the summer, water temperature in the upper 30 to $150 \mathrm{~m}$ of the northern SCS is up to $9^{\circ} \mathrm{C}$ cooler than that in the Kuroshio (Chen et al. 2003). The presence of the lesssaline surface water further supports the importance of riverine mixing. Both our Sb-ADCP data (Fig. 5) and the absolute geostrophic velocities data (Fig. 6) showed a strong eastward shift of post-typhoon currents from the SCS to the Kuroshio along Transect K, suggesting mass transportation after the typhoons.

\section{Fate of enhanced phytoplankton production}

The phytoplankton community changed from one favoring Trichodesmium spp. to one favoring diatoms 
after the typhoons, which supports the idea that more of the enhanced biogenic carbon is exported to deep waters (Dugdale \& Wilkerson 1998) than recycled in the shallow-water food web. Unlike diatoms, Trichodesmium spp. are positively buoyant and their biomass loss to sinking appears to be minor compared to cell lysis, extracellular release, and grazing (Mulholland 2007). Contrary to the traditional view that increased turbulence favors buoyancy and prevents sinking of nonmotile organisms such as diatoms, turbulence from typhoons is a stress that increases sinking of phytoplankton cells. In an experiment with 4 phytoplankton species, including 2 diatoms, Ruiz et al. (2004) demonstrated that cell-sinking velocity increased when culture water turbulence was intensified. As the typhoons pass, the ensuing shift to diatom domination and prolonged agitation of surface water would favor exportation over accumulation or recycling of biogenic carbons. The area of the region that would be affected by the riverine input could cover most of the near-shore waters along the coast of southern Taiwan. However, an estimation of additional new carbon that could be exportable due to the typhoons is beyond the scope of the present study. Future studies evaluating these changes in term of carbon, such as converting cell numbers of phytoplankton to biovolume and then carbon concentration, could show the relative importance of the typhoon events and how they would affect the carbon cycle. Maximum potential intensity of typhoons is projected to increase by 12 to $20 \%$ if atmospheric $\mathrm{CO}_{2}$ concentrations double (Pittock 1999). How this impacts on new production and sinking flux of carbon in this region remains to be studied.

In summary, the increased riverine discharge from the intensified precipitation from typhoons flooded a broad area off southern Taiwan and was the source of less-saline surface water in the upstream Kuroshio. Release from nutrient limitation by riverine mixing rather than by typhoon-induced upwelling was more the cause of the enhanced $\mathrm{PP}$ and $\mathrm{NO}_{3}-\mathrm{NP}$ in the upstream Kuroshio measured days after the passage of the typhoons. A clear regime shift from Trichodesmium spp. to diatom dominance supports the assertion that the biogenetic carbon enhanced by the typhoons tended to sink rather than be recycled in the upperwater food web.

Acknowledgements. We thank Y. H. Lin, C. C. Huang, and H. Sen for their assistance in sample collection and analyses, the captains and crews of RV 'Ocean Researcher' I and III for their cooperation, and Sea Pen Scientific Writing for editing services. This research was in part supported by the National Science Council of Taiwan through Grants NSC 95-2611M110-002, NSC 95-2611-M110-004, NSC 96-2611-M110-013, and NSC 96-2628-M110-005.

\section{LITERATURE CITED}

Babin SM, Carton JA, Dickey TD, Wiggert JD (2004) Satellite evidence of hurricane-induced phytoplankton blooms in an oceanic desert. J Geophys Res 109:C03043, doi:10.29/ 2003JC001938

Behrenfeld MJ, Falkowski PG (1997) Photosynthetic rates derived from satellite-based chlorophyll concentration. Limnol Oceanogr 42:1-20

Brand LE (1994) Physiological ecology of marine phytoplankton. In: Winter A, Siesser W (eds) Coccolithophores. Cambridge University Press, Cambridge, p 39-49

Campbell L (2001) Flow cytometric analysis of autotrophic picoplankton. Methods Microbiol 30:317-343

Carpenter EJ, Price C (1976) Marine Oscillatoria (Trichodesmium): explanation for aerobic nitrogen fixation without heterocysts. Science 191:1278-1280

Chen YLL (2005) Spatial and seasonal variations of nitratebased new production and primary production in the South China Sea. Deep-Sea Res I 52:319-340

Chen YLL, Chen HY (2006) Seasonal dynamics of primary and new production in the northern South China Sea: the significance of river discharge and nutrient advection. Deep-Sea Res I 53:971-986

Chen YLL, Chen HY, Lin YH (2003) Distribution and downward flux of Trichodesmium in the South China Sea as influenced by the transport from the Kuroshio Current. Mar Ecol Prog Ser 259:47-57

> Chen YLL, Chen HY, Chung CW (2007) Seasonal variability of coccolithophore abundance and assemblage in the northern South China Sea. Deep-Sea Res II 54:1617-1633

Chen YLL, Chen HY, Tuo S, Ohki K (2008) Seasonal dynamics of new production from Trichodesmium $\mathrm{N}_{2}$ fixation and nitrate uptake in the upstream Kuroshio and South China Sea basin. Limnol Oceanogr 53:1705-1721

Chern CS, Wang J (1998) The spreading of the South China Sea water to the east of Taiwan during summertime. Acta Oceanogr Taiwanica 36:97-109

Cochlan WP, Harrison PJ, Denman KL (1991) Diel periodicity of nitrogen uptake by marine phytoplankton in nitraterich environments. Limnol Oceanogr 36:1689-1700

Davis CS, McGillicuddy DJ Jr (2006) Transatlantic abundance of the $\mathrm{N}_{2}$-fixing colonial cyanobacterium Trichodesmium. Science 312:1517-1520

> Dortch Q (1990) The interaction between ammonium and nitrate uptake in phytoplankton. Mar Ecol Prog Ser 61: 183-201

> Dugdale RC, Wilkerson FP (1998) Silicate regulation of new production in the equatorial Pacific upwelling. Nature 391:270-273

DuRand MD, Olson RJ, Chisholm SW (2001) Phytoplankton population dynamics at the Bermuda Atlantic time series station in the Sargasso Sea. Deep-Sea Res II 48:1983-2003

> Fang MD, Chang WK, Lee CL, Liu JT (2009) The use of polycyclic aromatic hydrocarbons as a particulate tracer in the water column of (Gaoping) Kaoping submarine canyon. J Mar Syst 76:457-467

Garside C (1982) A chemiluminescent technique for the determination of nanomolar concentrations of nitrate and nitrite in seawater. Mar Chem 11:159-167

Gill AE (1982) Atmosphere-ocean dynamics. International geophysics, Vol 30. Academic Press, San Diego, CA

> Glover HE, Prézelin BB, Campbell L, Wyman M, Garside C (1988) A nitrate-dependent Synechococcus bloom in surface Sargasso Sea water. Nature 331:161-163

> Goldsmith ST, Carey AE, Lyons WB, Kao SJ, Lee TY, Chen J (2008) Extreme storm events, landscape denudation, and 
carbon sequestration: Typhoon Mindulle, Choshue River, Taiwan. Geology 36:483-486

James RT, Chimney MJ, Sharfstein B, Engstrom DR, Schottler SP, East T, Jin KR (2008) Hurricane effects on a shallow lake ecosystem, Lake Okeechobee, Florida (USA). Fundam Appl Limnol 172:273-287

> Jan S, Chern CS, Wang J (2002) Transition of tidal waves from the East to South China Seas over the Taiwan Strait: influence of the abrupt step in the topography. J Oceanogr 58: $837-850$

Kustka A, Sanudo-Wilhelmy S, Carpenter EJ, Capone DG, Raven JA (2003) A revised estimate of the iron use efficiency of nitrogen fixation, with special reference to the marine cyanobacterium Trichodesmium spp. (Cyanophyta). J Phycol 39:12-25

Letelier RM, Karl DM (1996) Role of Trichodesmium spp. in the productivity of the subtropical North Pacific Ocean. Mar Ecol Prog Ser 133:263-273

Letelier RM, Karl DM (1998) Trichodesmium spp. physiology and nutrient fluxes in the North Pacific subtropical gyre. Aquat Microb Ecol 15:265-276

Liang WD, Tang TY, Yang YJ, Ko MT, Chung WS (2003) Upper-ocean currents around Taiwan. Deep-Sea Res II 50:1085-1105

Lin I, Liu WT, Wu CC, Wong GTF and others (2003) New evidence for enhanced ocean primary production triggered by tropical cyclone. Geophys Res Lett 30:1718

Lindell D, Post AF (1995) Ultraphytoplankton sucession is triggered by deep winter mixing in the Gulf of Aqaba (Eilat), Red Sea. Limnol Oceanogr 40:1130-1141

Liu JT, Lin HL, Hung JJ (2006) A submarine canyon conduit under typhoon conditions off Southern Taiwan. Deep-Sea Res I 53:223-240

McIntyre A, Bé AWH, Roche MB (1970) Modern Pacific coccolithophorids: a paleontological thermometer. Trans NY Acad Sci 32:720-731

Moore LR, Post AF, Rocap G, Chisholm SW (2002) Utilization of different nitrogen sources by the marine cyanobacteria Prochlorococcus and Synechococcus. Limnol Oceanogr 47:989-996

Mulholland MR (2007) The fate of nitrogen fixed by diazotrophs in the ocean. Biogeosciences 4:37-51

Mulholland MR, Shoemaker C, Ohki K, Capone DG (1999) Utilization of combined forms of $\mathrm{N}$ in cultures and field

Editorial responsibility: Rodney Forster, Lowestoft, UK populations of Trichodesmium. In: Charpy L, Larkum AWD (eds) Marine cyanobacteria. Bull Inst Oceanogr Monaco Spec Issue 19:279-286

> Ning SK, Chang NB, Yang L, Chen HW, Hsu HY (2001) Assessing pollution prevention program by QUAL2E simulation analysis for the Kao-Ping River Basin, Taiwan. J Environ Manage 61:61-76

Paerl HW, Valdes LM, Peierls BL, Adolf JE, Harding LW Jr (2006) Anthropogenic and climatic influences on the eutrophication of large estuarine ecosystems. Limnol Oceanogr 51:448-462

Pittock A (1999) Coral reefs and environmental change: Adaptation to what? Am Zool 39:10-29

> Raven JA (1988) The iron and molybdenum use efficiencies of plant growth with different energy, carbon and nitrogen sources. New Phytol 109:279-287

Ruiz J, Macias D, Peters F (2004) Turbulence increases the average settling velocity of phytoplankton cells. Proc Natl Acad Sci USA 101:17720-17724

Siswanto E, Ishizaka J, Yokouchi K, Tanaka K, Tan CK (2007) Estimation of interannual and interdecadal variations of typhoon-induced primary production: a case study for the outer shelf of the East China Sea. Geophys Res Lett 34: L03604

Son S, Platt T, Fuentes-Yaco C, Bouman H, Devred E, Wu Y, Sathyendranath S (2007) Possible biogeochemical response to the passage of Hurricane Fabian observed by satellites. J Plankton Res 29:687-697

Thomson-Bulldis A, Karl D (1998) Application of a novel method for phosphorus determinations in the oligotrophic North Pacific Ocean. Limnol Oceanogr 43:1565-1577

> Vaulot D, Courtiest C, Partensky E (1989) A simple method to preserve oceanic phytoplankton for flow cytometric analyses. Cytometry 10:629-635

Walker ND, Leben RR, Balasubramanian S (2005) Hurricaneforced upwelling and chlorophyll a enhancement within cold-core cyclones in the Gulf of Mexico. Geophys Res Lett 32:L18610

> Yuan J, Miller RL, Powell RT, Dagg MJ (2004) Storm-induced injection of the Mississippi River plume into the open Gulf of Mexico. Geophys Res Lett 31:L09312

Zhang W, Wang R (2000) Rapid changes in stocks of ciliate microzooplankton associated with a hurricane in the Bohai Sea (China). Aquat Microb Ecol 23:97-101

Submitted: January 5, 2009; Accepted: April 8, 2009 Proofs received from author(s): June 8, 2008 